\title{
THE CEMETERY OF FRONTOVOE 3
}

\author{
New data on the culture of the Crimea \\ in the Roman and Early Great Migration periods ${ }^{1}$
}

\section{Igor Gavritukhin - Larisa Golofast - Anna Mastykova - Evgeny Sukhanov - Alexey Sviridov - Sergey Yazikov}

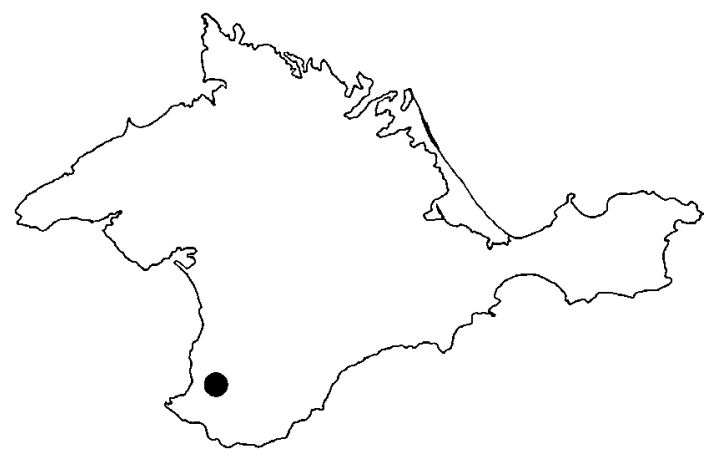

DOI: https://doi.org/10.31577/szausav.2021.68.4

Keywords: south-western Crimea, Roman period, Great Migration period, cemetery, spatial structure, periodization, funeral rite, accompanying goods.

This article publishes an account of a new flat cemetery located near modern Frontovoe village (Nakhimovskii district, Sevastopol), which was discovered and completely researched by a team of the Institute of Archaeology of the Russian Academy of Sciences during the rescue works of 2018. The cemetery in question appeared in the late $1^{\text {st }} \mathrm{c}$. AD and existed as long as the early $5^{\text {th }} \mathrm{c}$. AD. Chronological zones of the cemetery have been determined, particularly considering the dates of 40 coins plus. The article supplies a characteristic of funeral rites and main categories of the finds, particularly about 15,000 beads, 800 vessels plus, and about 4,000 other artefacts (mostly metal ware).

\section{GENERAL INFORMATION}

The archaeological site called Frontovoe 3 (Russian Фронтовое 3, also Latinised as Frontovoye 3) was located within administrative borders of modern Sevastopol, in the Nakhimovskii district, $1 \mathrm{~km}$ to the west-south-west from modern Frontovoe village (Fig. 1: 1). It was discovered in 2018 by a team from the Archaeological Heritage Preservation Department of the Institute of Archaeology of the Russian Academy of Sciences during the rescue works of the monuments and sites which appeared in the construction zone of the Taurida highway. The excavations were conducted by the Crimean Contract Archaeological Team of the Institute of Archaeology of the Russian Academy of Sciences (headed by S. Vnukov) in 2018; the field directors were S. Yazikov and A. Sviridov.

There are publications (Gavritukhin/Sviridov/Yazikov 2020; Yazikov/Sviridov/Aleinikov 2019) and presentations delivered at several scholarly conferences which supply brief accounts of the site in question. Complete publication of the site and a corpus of special researches are under work, with participation of a wide range of experts in specific categories of artefacts, along with palaeoanthropological and naturalscientific analyses.

The excavations of the site uncovered the area of $13,948 \mathrm{~m}^{2}$. The cultural layer was ploughed up. Among the finds, there are coins of Sahib Girey I bin Mengli Girey (1532-1550 AD) or Islam Girey II bin Devlet Girey (1584-1588 AD); Selim I bin Behadyr (1671-1704 AD); Selim II bin Kaplan (1743-1748 AD). ${ }^{2}$ In the south-eastern area of the excavations trench, the investigations revealed five pits with the Bronze Age materials and no significant finds.

The excavations in the main cemetery area uncovered four burial constructions from the Bronze Age and 328 graves from mostly Roman period. The cemetery related to the Roman period was excavated

\footnotetext{
1 The study is supported by the grant of the Russian Science Foundation, project 20-18-00396 "Barbarians and Rome in the South-Western Crimea: the interaction of cultures".

2 These coins have been attributed by I. Volkov; antique coins have been attributed by M. Abramzon.
} 


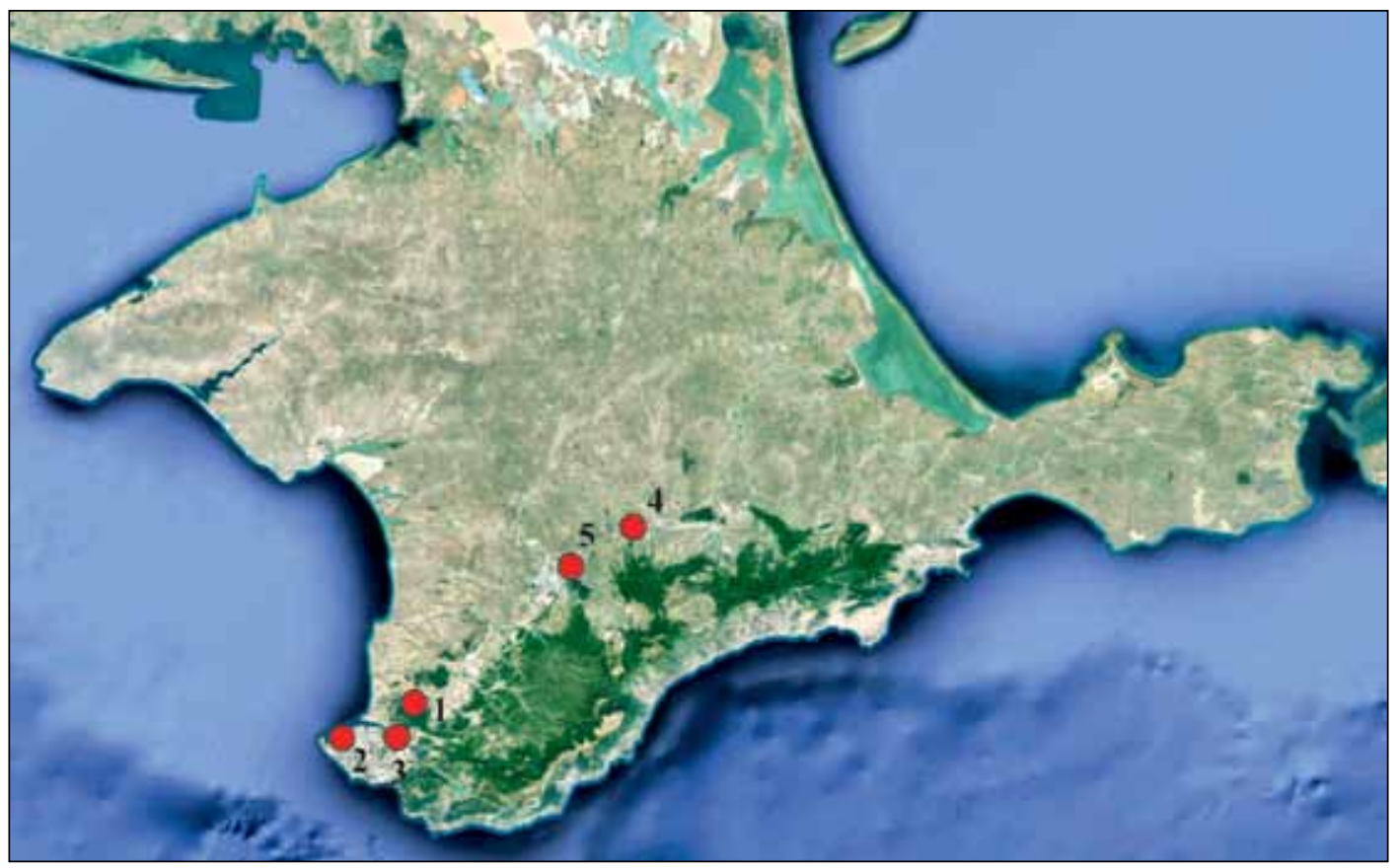

Fig. 1. Crimea. Location of the cemetery of Frontovoe 3 and the most cited sites. 1 - Frontovoe 3; $2-$ Chersonese; 3 - Sovkhoz 10; 4 - Neizats; 5 - Druzhnoe.

completely (Fig. 2: a). The burials from the Bronze Age appeared on two areas located far from each other (Fig. 2: b). Perhaps a part of the graves from this period was destructed in the Roman period. The presentday looters did not touch the site, which was a rare case not only for the Crimea. This paper supplies brief characteristics of the main part of the site as the cemetery from the Roman and the early stage of the Great Migration periods.

This cemetery was flat. The graves were as a rule located in lines, irrespective of their types. There are a few cases with overlapping graves. In top part of the infill of the pits of 20 plus graves located in the most part of the cemetery area, there occurred big isolated stones. Most probably, they were visible at the ancient daily surface and, possibly, were grave markers. Perhaps there also were other (non-documentable archaeologically) outer grave markers. From all the above-mentioned facts, it is evident that the persons who buried in this cemetery knew its ground-planning. The excavations of the site found about 20,000 finds, including about 15,000 beads and seed beads.

\section{SPATIAL STRUCTURE AND CHRONOLOGY}

The cemetery uncovers expressive spatial structure (planigraphy). Its northern area is densely filled with graves, though in the southern area graves are sparser (Fig. 2). According to selective analyses of the chronology of the grave goods, the spatial differences of graves correspond to the chronological evolution of the cemetery. Against this background, there are reasons to distinguish the areas of periods 1 and 2 , each comprising several zones of narrow chronologies.

\section{Zones of period 1 \\ (ca. the late $1^{\text {st }}$ to the first half of the $3^{\text {rd }}$ century AD)}

Chronological indicators from the last decades of the $1^{\text {st }}$ and the first half of the $2^{\text {nd }} \mathrm{c}$. (red-slip pottery and others; see below) concentrate in the north-west of the cemetery in question forming its chronological "core" (Fig. 2: c). Later on, the cemetery grew to the east and south, where two petal-shaped areas developed, with especial dense concentration of the graves. 


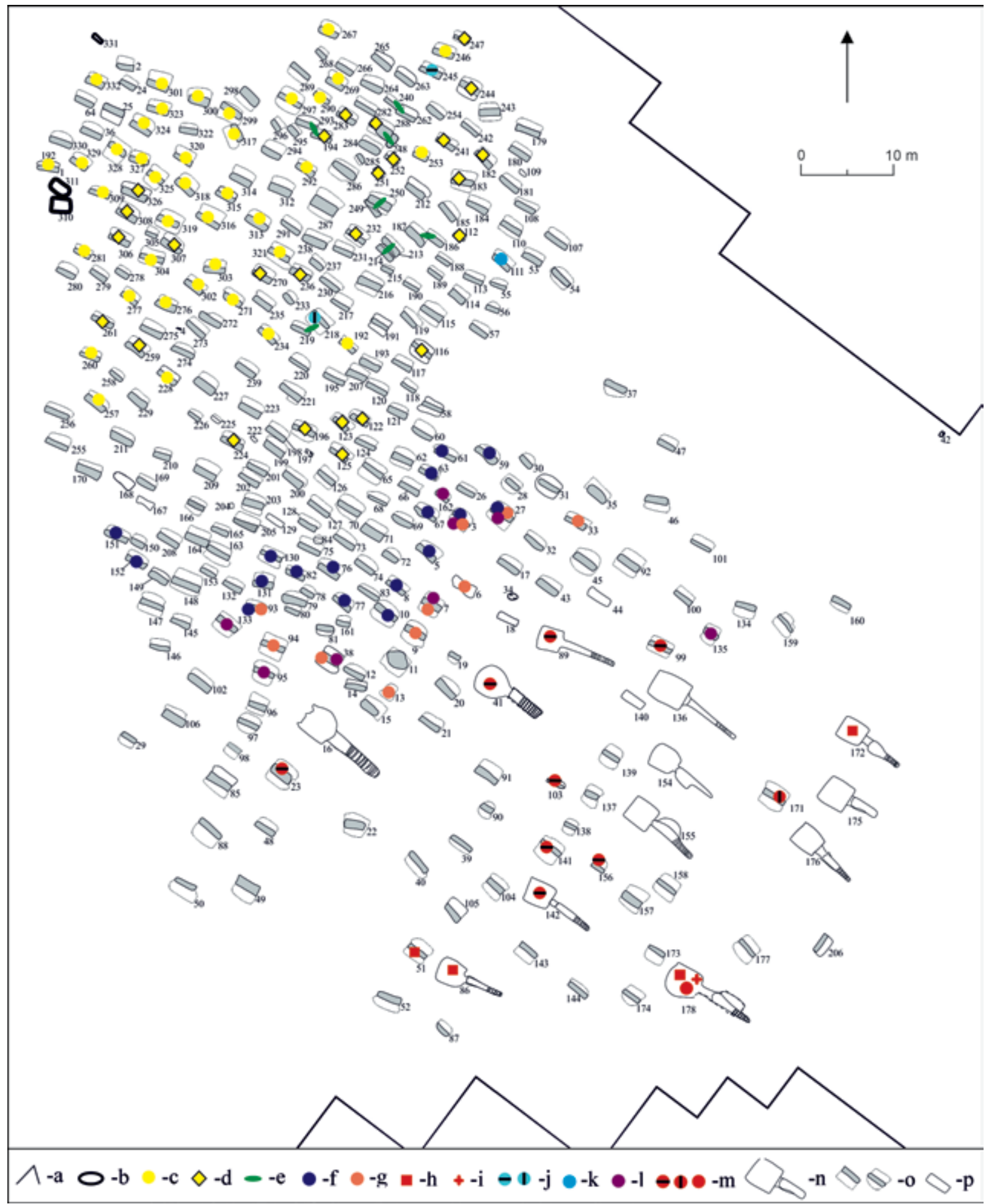

Fig. 2. Ground plan of the cemetery of Frontovoe 3. Legend: $a$ - the borderline of the excavation area; $b$ - Bronze Age graves; $\mathrm{c}$ - pottery from the late $1^{\text {st }}$ and first half of the $2^{\text {nd }} \mathrm{c}$; $\mathrm{d}$ - pottery from the $2^{\text {nd }} \mathrm{c}$.; $\mathrm{e}$ - overlapping graves; $\mathrm{f}-\mathrm{the}$ south-eastern periphery of the Ambroz-15-II brooches distribution area; $\mathrm{g}$ - the north-western periphery of the Ambroz-15-III brooches distribution area; $\mathrm{h}$ - the Hunnic period markers (from not earlier than the 370s AD); $\mathrm{i}-\mathrm{buckles}$ from the $5^{\text {th }} \mathrm{c} . ; \mathrm{j}$ - the latest coins of the complex (j1 - first half of the $1^{\text {st }} \mathrm{c} . ; \mathrm{j} 2-150-175 ; \mathrm{k}-$ late $2^{\text {nd }} / \mathrm{early} 3^{\text {rd }} \mathrm{c} . ; 1-\mathrm{mid}-3^{\text {rd }} \mathrm{c}$.; $\mathrm{m}-4^{\text {th }} \mathrm{c}$. (including $\left.\mathrm{m} 1-306-337, \mathrm{~m} 2-351-355\right) ; \mathrm{n}$ - burial vaults; $\mathrm{o}$ - single- and double-undercut graves; $\mathrm{p}-$ simple pit graves. 
In the western area of the eastern zone ("petal") of period 1 there are seven cases of the graves overlapping one other (Fig. 2: e). Plausibly, the cemetery of period 1 could not enlarge to the east by some reason, so new graves were constructed at places already developed. Grave goods from the overlapping burials are often not so distinctive to allow a narrow dating within period 1 . It should be mentioned that later grave as a rule touched only a side of the earlier one. It looks like those who buried there tried to find a space in between of the graves. Perhaps in some cases they succeeded, which is important when using the dating of the assemblages in this area of the site according to its spatial structure.

In the eastern zone of period 1 there are coins of Chersonese (Fig. 2: j) from the first half of the $1^{\text {st }} \mathrm{c} . \mathrm{AD}$ with a hole for wearing (grave 245) and of 150-175 AD (grave 218), and a Roman coin of bad preservation, from the late $2^{\text {nd }}$ or early $3^{\text {rd }} \mathrm{c}$. (grave 111; Fig. 2: k). Along with red-slip pottery (Fig. 2: c, d) and other finds, these coins determine the calendar date of the eastern zone of period 1.

The southern zone ("petal") of period 1 is partially synchronous to the eastern zone (Fig. 2: d). It shows the development of the cemetery from its "core" to the south, where this zone is the only of period 1 to gradually turn to the early zone of period 2 .

\section{Transition zone (ca. the middle to the $3^{\text {rd }}$ quarter of the $3^{\text {rd }}$ century)}

Regarding the grave goods, the border between the periods of the cemetery development is strikingly marked with the change of single-piece bow-shaped brooches with a returned foot (Fig. 2: f) with twopiece bow-shaped artefacts with a returned foot (Fig. 2: g).

In this strip of graves, there is a group of burials containing one to seven coins each (Fig. 2: 1). Apart from the only exception, ${ }^{3}$ there are a few denarii and (the overwhelming majority of the coins) antoniniani from the $3^{\text {rd }}$ c.: of Septimius Severus (193-211), Plautilla (202-211/212), Gordianus III (238-244), Philip I Arab (244-249), Trebonianus Gallus (251-253), and Gallienus (253-268). The latest in this group are: a coin from $240 \mathrm{AD}$ (grave 162, there were two coins in total), a coin from 244-247 (grave 3, there were seven coins), a coin from 246-248 (grave 133, the only in this burial), a coin from 251-253 (grave 95, the only in this burial), a coin from 253-268 (grave 27, there were two coins), a coin from 258-259 (grave 7, there were four coins), and a coin from the mid- $3^{\text {rd }} \mathrm{c}$. (grave 38, there were two coins). The overwhelming majority of the coins in question were minted in Rome and Mediolanum; the only exception is grave 7 containing the latest coins of the group, which were minted in the Asiatic provinces of the Roman empire.

There is no doubt about the connection of this set with the period of the so-called Scythian ("Gothic") wars. The changes reflecting their consequences for the south of Eastern Europe are documented by a series of innovations in the culture of period 2 of the cemetery of Frontovoe 3. However, there is obvious continuity of the local population's traditions in several groups of grave goods, main funeral rites, and the structure of the cemetery.

\section{Zones of period 2 \\ (ca. the second half of the $3^{\text {rd }}$ to the early $5^{\text {th }}$ century)}

From the transition zone on, the cemetery widens to the east and south. The early zone of period 2 contained mostly artefacts (brooches, buckles), which combination was typical of the periods synchronous to the stage C2 (250/260-300/320) in the European Barbaricum. However, there also appeared the finds typical of the stage C3 (300/320-350/370); in the late (southern) part of this zone there were burial vaults (Fig. 2: n).

Although there were rather wide empty places to the south of the first line of the vaults, the set of burial structures and funeral rites in the graves located to the south-east of the empty areas did not change. Nevertheless, there was no find synchronous to stage $\mathrm{C} 2$, so we have interpreted these graves as the medium zone of period 2 (about the first half to the third quarter of the $4^{\text {th }} \mathrm{c}$.). The graves located at the westernmost and easternmost places of the area of period 2 did not possess narrow dates; by all appearance, they were mostly synchronous to the latest graves in the early zone or/and the medium zone graves.

\footnotetext{
3 The second coin in grave 162 is a drachma of Ariobarzanes I (95-63 BC; Cappadocia), a type extremely rare in the Crimea.
} 
In the latest part of the early zone (about the late $3^{\text {rd }}$ and the first decades of the $4^{\text {th }} \mathrm{c}$.) and in the medium zone there are very few coins from the early period, particularly an antoninianus from 247-249 AD (Rome; the only coin in grave 135; Fig. 2: 1), though the folles from the age of Constantine the Great predominated (Fig. 2: $\mathrm{m} 1$ ). The latest finds were a coin from 309-310 (grave 103, there were three coins in this burial), a coin from 312-313 (grave 142, the only coin in this burial), a coin from 313 (grave 41, the only coin), coins from 313-314 (grave 89, the were three coins; grave 99, the only coin in this burial), a coin from 324-325 (grave 23, the only coin in this burial), a coin from the 320s (grave 141, the only coin in this burial), and a coin perhaps from 306-337 (grave 156, the only coin in this burial). All the specimens showing a determinable mint mark were issued in the eastern provinces of the Roman Empire.

In the same area as the above-mentioned coins and artefacts synchronous to the stage C 3 and in the latest zone, there appeared numerous finds of dishes featuring forms 1 and 2 of the Pontic Red Slip Ware, which dated from the mid- $4^{\text {th }}$ to mid- $5^{\text {th }}$ c. (Arseneva/Domzalski 2002, 426).

The latest zone of the graves from period 2 and the cemetery in general (ca. the fourth quarter of the $4^{\text {th }}$ and early $5^{\text {th }} \mathrm{c}$.) is determined by a line at its south-eastern border and a strip of southernmost graves. Two of these graves (51 and 172) contained belt fittings and a glass cup dating to not earlier than the 370s, and another grave (178) contained buckles typical of stage D2 (380/400-440/450; Fig. 2: h, i; $7: 1 ; 11: 1-4,9$ ). Grave 171 located close to the south-easternmost line of burial vaults contained two bronze Roman coins from 351-355, and in grave 178, which included the latest grave goods, there was a copper coin of poor preservation, possibly a Roman piece from the $4^{\text {th }}$ c. (Fig. 2: $\mathrm{m} 2$, 3). Since there is the only grave containing thee finds from the stage D2, we have supposed that the cemetery ceased to exist in the early part of this stage, about the early $5^{\text {th }} \mathrm{c}$.

Grave 206 that marked the south-eastern limit of the cemetery showed specific orientation and, unfortunately, contained no grave goods. Perhaps, its particulars indicate the moment when the population ceased to use this cemetery.

\section{FUNERAL RITES}

In comparison with many synchronous sites in the Crimea, the funeral rituals documented at the Roman period cemetery of Frontovoe 3 were not varied. In total, there were 305 pits with undercuts, 12 burial vaults, 3 shouldered pits with burials and in most cases grave goods; 3 simple pits with burials of animals and 1 pit with no finds (grave 129); 1 amphora grave and 3 objects destroyed by modern builders before the excavations started. In total, there were 328 constructions, including 4 structures related to the Roman period cemetery with different degrees of probability, though the attribution of the others is beyond doubts.

\section{Undercut graves}

Undercut graves predominated in the most cemetery area (Fig. 2: o). Their entrance pits are almost rectangular, measuring up to $0.7 \mathrm{~m}$ in width and 2.2-2.4 $\mathrm{m}$ in length, with a few structures up to $2.6 \mathrm{~m}$ long. Undercuts carved into the north-eastern wall of the pit predominated; much smaller number of the graves had undercuts in both long walls (Fig. 3: 2, 3); there also are a few pits with the undercut in the south-western wall (as on Fig. 3: 1). There is no cemetery zone where these grave variants concentrated. The only undercut grave located in the south-eastern border of the cemetery was oriented from the south-west to north-east.

Apart from a few cases, the undercuts had the floor as deep as that of the entrance pit. The undercuts were 0.43 to $0.7 \mathrm{~m}$ wide; in most cases, they were longer than the entrance pit, up to $2.6 \mathrm{~m}$. As a rule, the undercut had a stone barrier represented by two types of almost equal proportion: formed by horizontal and vertical stones, often in aslant position (Fig. 3: 1, 2), or of irregular heaps of stones. Graves from period 1 sometimes had no stone barrier; in other cases, there were singular stones or stones forming a line on the floor (Fig. 3: 3). In a few instances, these stones were placed near the head, pelvis, or legs like a support for the body. There are a very few cases when the entrance pit was filled with a rubble mass. More often, the upper layers of the infill of the pit contained one or a few big stones possibly related with above-grave constructions which were visible in antiquity.

\footnotetext{
4 For a detailed characteristic of the funeral rituals see Sviridov/Yazikov 2019.
} 


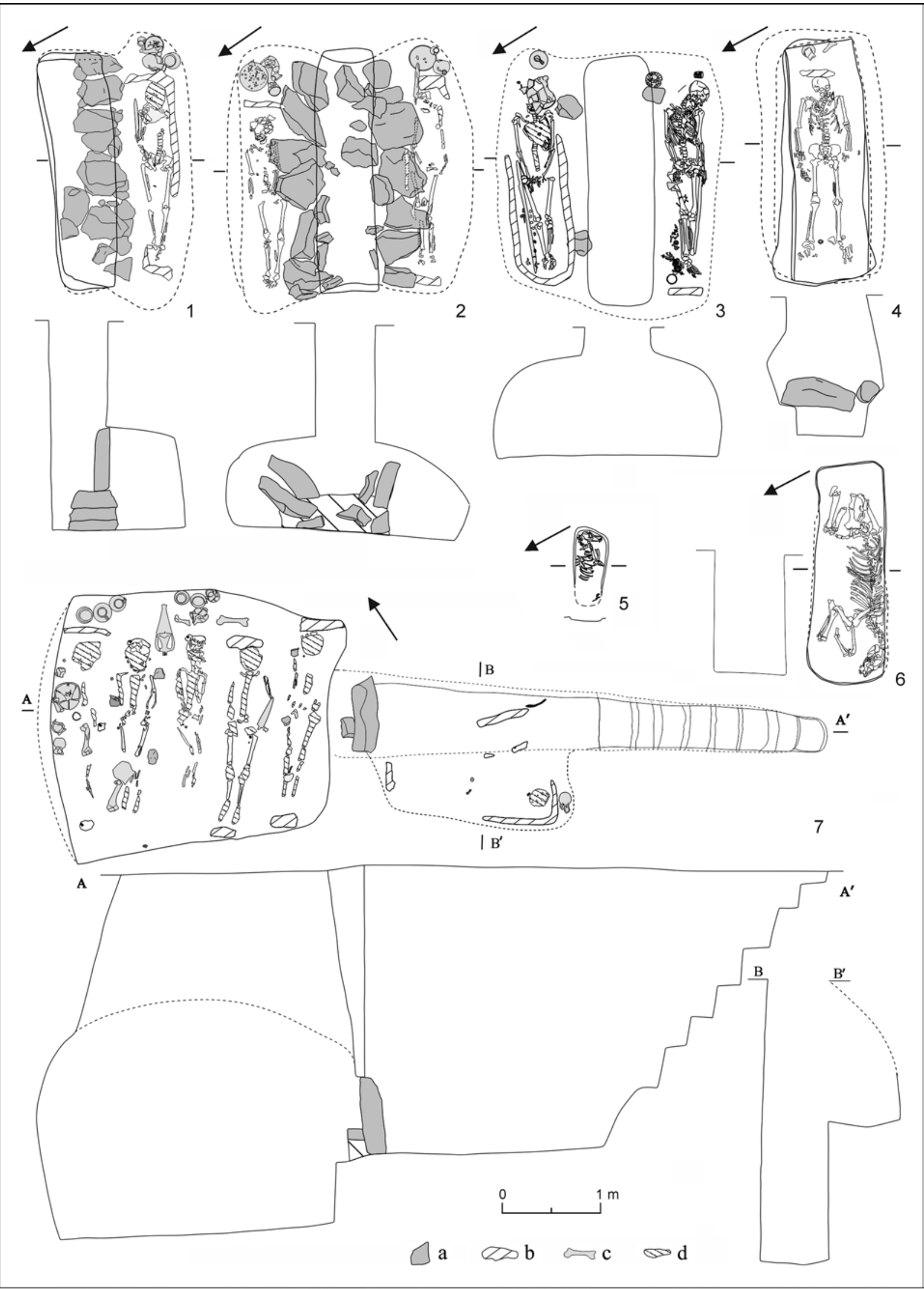

Fig. 3. The cemetery of Frontovoe 3. Funeral rites. 1 - grave $52 ; 2$ - grave $171 ; 3$ - grave 319; 4 - grave $44 ; 5$ - grave 222; 6 - grave 18; 7 - grave 154. Legend: a - stones; $\mathrm{b}$ - ashes of wood; $\mathrm{c}$ - animal's bone; $\mathrm{d}$ - ashes of bones. 
The undercut burials mostly were inhumations. As a rule, each undercut contained one burial. The orientation of the dead with the head to the south-eastern sector predominated. In most cases, dead persons laid on the back, with the hands stretched along the body (Fig. 3: 1, 2), or with one or both hands slightly bent (Fig. 3: 3, to the left); the legs were stretched, and sometimes joined together at the knees or, rarely, at the feet. Sometimes there appeared flexed skeletons.

There are two cases in the early zone of period 1 featuring two burials in the same undercut. In grave 328, the secondary burial was made with moving aside the bones and grave goods that already were there to the wall of the undercut. In grave 317, a woman's skeleton was located above a man's, in a way to make the head of the top person not covering the head of the bottom one.

Collective burials in the same undercut are documented three times, in the early and medium zones of period 2 or near it. In grave 94, a child's burial accompanied with grave goods was unearthed in between of the long bones of the legs of an adult person. In grave 91, one burial was made above another, with a thin separating layer of soil. One of the undercuts of grave 45 contained four skeletons, with the bones of all these persons were removed and placed as accumulation.

There were 90 burials in all the cemetery zones featuring remains of wood, mostly as organic ashes, including two cases when coffin lids partially survived above the skeleton, and in seven graves there were remains of wooden trunks (Fig. 3: 3, to the left).

Cremations were documented only in the undercut graves located in the latest (southern) zone of period 1 or at the junctions with the early zone of period 2 . All the cremations were made outside the cemetery. In eight cases, they used specific graves; in four cases, specific burial chambers were made for cremation and inhumation burials; in three cases, inhumation and cremation burials were placed in the same undercut, with one case when cremated bones were placed on the chest, in the other case on the shin bones of inhumation burial, and in the third case amidst the stones of the barrier separating undercut from the entrance pit.

\section{Burial vaults}

Burial vaults (Fig. 3: 7) date to period 2 only (Fig. 2: n), with three structures located in the latest area of its early zone, four structures in the medium zone, and five in the latest zone. Taking the coins and other grave goods into account, all the vaults date from the $4^{\text {th }} \mathrm{c}$.

All the burial vaults had the burial chamber as the continuation of the long axis of the entrance pit; they were oriented from the north-west to the south-east, with the entrance to the burial chamber from the south-east. The chambers featured a sub-rectangular ground-plan measuring from $2.2 \times 2.3 \mathrm{~m}$ to $2.7 \times 3 \mathrm{~m}$. The domed vaulting remained at one chamber, measuring ca. $2.4 \mathrm{~m}$ in height. The entrance pits measured 2.1 to $5.2 \mathrm{~m}$ in length, with five to eight steps, usually forming an obtuse angle, each of no more than $0.3 \mathrm{~m}$ in length. The dromoi (passageways to the burial chamber) were $0.3-0.7 \mathrm{~m}$ long, with that in the latest vault (178) $1.1 \mathrm{~m}$ long. All the vaults had barriers of vertically placed, flattened stones, each measuring $0.8-0.9 \mathrm{~m}$ in height and $0.5-1 \mathrm{~m}$ in width. In six cases, when the stones were placed aslant, the vaults kept traces of post-funeral disturbance done in antiquity.

The vaults contained the remains of 34 persons, one to six skeletons in a structure. There are seven vaults with buried remains in anatomical order and five with disturbed bones. According to palaeoanthropological data, the vaults contained burials of five and six individuals (each in one case), three individuals (in four cases), one, two, or four persons (each in two cases). Vault 86 (Gavritukhin et al. 2020, fig. 4) with two buried persons definitely remained unfilled to the end. Considering its location on the cemetery edge, it was caused by the end of the cemetery use (cf.: Khrapunov 2005, 178).

All the skeletons (apart from a single burial in the entrance pit) were placed on the floor of burial chambers, stretched on the back. In the early vaults, the dead laid along the long axis of the structure; in other cases, when the remains were documented in situ, they laid perpendicularly to the main axis of the vault. In some cases, the dead laid with the heads to the feet, in opposite position; there are traces of wooden structures remained at the head or the feet of many skeletons.

\section{Pits with ledges}

Pits with ledges in their long walls (Fig. 3: 4), three in number, appeared on the edge of the early and medium zones of period 2. The orientation of these pits and the location of the deceased were the same 
as of the main bulk of undercut graves. The ledges were up to $0.3 \mathrm{~m}$ wide; they were located at the height of $0.4-0.7 \mathrm{~m}$ from the pit bottom. In two cases, they supported stone slabs covering the graves, and in one case plausibly a wooden block which traces did not survive.

\section{Simple pit burials}

Simple pit burials occurred two times in the southern zone of period 1 (graves 197 and 222); they were not deep; each structure contained one dog's skeleton (Fig. 3: 5). Grave 18 (the latest area of the early zone of period 2) contained a horse's burial laying on the left side, with contracted legs, in a rectangular pit measuring $2.1 \times 0.7 \mathrm{~m}, 0.8 \mathrm{~m}$ deep (Fig. 3: 6). All the animal's burials possessed no grave goods.

\section{Ancient penetrations}

Ancient penetrations causing the disturbance of skeletal bones and the extraction of a part of them together with grave goods from the burial structure has been documented in four burial vaults of the late zone and one vault from the medium zone of period 2, and also in 12 undercut graves located in every zone of period 2 and in the late zone of period 1 . There are some cases in this group when only isolated bones or fine goods survived; there often survived precious artefacts, undisturbed or laying in the infill, such as a silver solid buckle remaining in the infill of grave 178 (Fig. 11: 1). Obviously, those who made a part of such penetrations into graves (or, possibly, all such cases) were not looters.

\section{Grave goods location}

Grave goods location in undisturbed burials does not have unusual variants. The pieces of attire have been documented at place where usually worn. Offensive weapons were put close to the owner. According to the find spots of shield bosses, the shields were leaned to the walls of the burial chambers of vaults 41 and 136. As a rule, horse tack details were placed at the feet of the dead. Ceramic and glass vessels were usually placed at the head of the dead, often in niches. Animal's bones often laid nearby. Iron knives in graves of period 1 often appeared in shallow open-form vessels; as a rule, graves from period 2 contained iron knives near animal's bones or just on top of them.

\section{General commentaries}

The funeral rites of the cemetery of Frontovoe 3 generally belong to the range of rituals documented at synchronous sites in the south-western and sub-mountainous Crimea. Among the specificities is the great percentage of undercut graves. Closer to the final of the cemetery only, there increased the number of burials in vaults, following the trend also traced in other sites which were excavated at large areas.

In most cemeteries in the south-western and sub-mountainous Crimea, in contrast to Frontovoe 3, there was no cremation grave. At the sites where cremations appeared, they featured other types and variants of this rite (Aibabin 1999, 24; Dasherskaia 1991, 27; Strzheletskii et al. 2003-2004, 47-54). For some researchers, the appearance of cremated graves in the Crimea was related to the migration of Germanic tribes during the age of the Scythian Wars or just after them (Aibabin 1999, 26; Khrapunov 2002, 79). However, the materials of Frontovoe 3 contradict this reconstruction because of their chronology.

In the cemetery of Frontovoe 3, burial vaults possessed a chamber prolonged along the axis of the entrance pit, in contrast to several cemeteries in the south-western Crimea and the overwhelming majority of graves in the sub-mountainous Crimea, where the vaults featured T-shaped ground plan. In the said areas, there are rare cases of the skeletons placed perpendicularly to the axis of the entrance pit, which was typical of Frontovoe 3, apart from the earliest vaults in the latter cemetery.

The mentioned specificities do not allow us to consider that the population that created the cemetery of Frontovoe 3 was foreign in the Crimea. 
By all appearance, the cemetery in question was used by a single community. Throughout period 1 , their burial practises became homogenous. Perhaps not so long before the end of period 1, a part of the population got detached, for the following use of the cemetery in question was related to the population group that developed the southern zone of period 1. It is still possible that, at certain stages of its history, the community received newcomers; anyway, in course of time and in period 2, the rituals were unified and developed in the same direction.

\section{CERAMIC POTTERY}

The graves in the cemetery of Frontovoe 3 contained 587 ceramic vessels. The biggest group comprises red-slip ware (402 pieces).

\section{Red-slip ware}

There are categories of red-slip ware, such as plates, table amphorae, mugs, cups, and bowls, which appeared only in graves from period 1. Red-slip plates are represented by forms $1-4^{5}$ (Fig. 5: 2-5), including the pieces featuring planta pedis stamps and marking the earliest graves in the cemetery (about the last quarter/late $1^{\text {st }}-$ first half of the $2^{\text {nd }} c$ c.). Among the mugs, especially numerous is form 1 (Fig. 4: 20), though forms 4 and 8 comprise a few pieces (Fig. 4: 21). Table amphorae feature forms 1.1, 1.3, and 2 (Fig. 4: 15-17). The bowls correspond to forms 24.1, 28, and 30.3 (Fig. 5: 6, 15, 16). The cups feature form 31 (Fig. 5: 9). The set is augmented by oenochoes (Fig. 4: 22) and kantharoi (Fig. 5: 17). Rare but impressive finds from graves of period 1 are fish-plates (Fig. 5: 18). There is a unique red-slip vessel in the form of a bull (Fig. 5: 1), originating from grave 317 in the early zone of period 1.

Pitchers form the biggest category featuring most varied forms of the red-slip ware. The graves of period 1 contained the most demonstrative pitchers of forms 2.1 (Fig. 4: 6), 4 (Fig. 4: 1), and 20.1 (Fig. 4: 5). Forms 37 (Fig. 4: 7) and 39 (Fig. 4: 10) are documented also in the graves from the transition period. Graves from period 2 contained pitchers of V. Nessel's types IV.2 (Fig. 4: 19) and IV.4 (Fig. 4: 18; Nessel 2003).

In period 1, there were demonstrative bowls of forms 10 and 14.3 (Fig. 5: 7, 8). In the graves from period 2 there were bowls of types 4, 6, and 7 (Fig. 5: 10-12) according to the classification of the finds from the cemetery of Sovkhoz 10 (Ushakov/Doroshko/Doroshko 2017; they correspond to types 4, 3, and 6 of Strzheletskii et al. 2003-2004), which name derived from the title of the nearby collective farm.

Among the oil-lamps, there is one artefact (type Loeschcke-VIII) discovered in a grave from period 1 (Fig. 5: 13), three (the group Biconical Oil-Lamps; Fig. 5: 14) in the burials from period 2 (Chrzanovski/ Zhuravlev 1998, 14, 79).

Only the graves in the middle and late zones of period 2 contained red-slip dishes of forms 1 and 2 (Fig. 5: 19, 20) of K. Domzalski's Pontic Red-Slip Ware (Arseneva/Domzalski 2002).

As it has already been stated, the red-slip ware is typical mostly for the graves from period 1 . This group of finds laid the background for its periodization and calendar dating (Fig. 2: c, d). In the graves from period 2, the assortment and number of red-slip ware greatly diminished, so its variety is restricted to two types of pitchers, three types of bowls, and two types of plates. However, in this period it also was an important chronological reference point. One may suppose that the decline of the number and variety of red-slip vessels in the graves of period 2 is related to the break of economic relations and the decline of the volume of imports after the so-called Scythian ("Gothic") Wars in the mid- $3^{\text {rd }} \mathrm{c}$.

\section{Other wheel-made vessels}

Other wheel-made vessels comprise 11 specimens. In the early zone of period 1 there were four plates and one cup with the surface and break of dark gray colour and no slip covering. Although the forms of these vessels are closest to the plates Hayes-63 and (Fig. 5: 21) cups Hayes-70 of the Eastern Sigillata B2, their technological features do not meet the parameters typical of this ceramic ware group (Hayes 1985;

\footnotetext{
5 Henceforth the form numbers are given according to D. Zhuravlev (2010).
} 


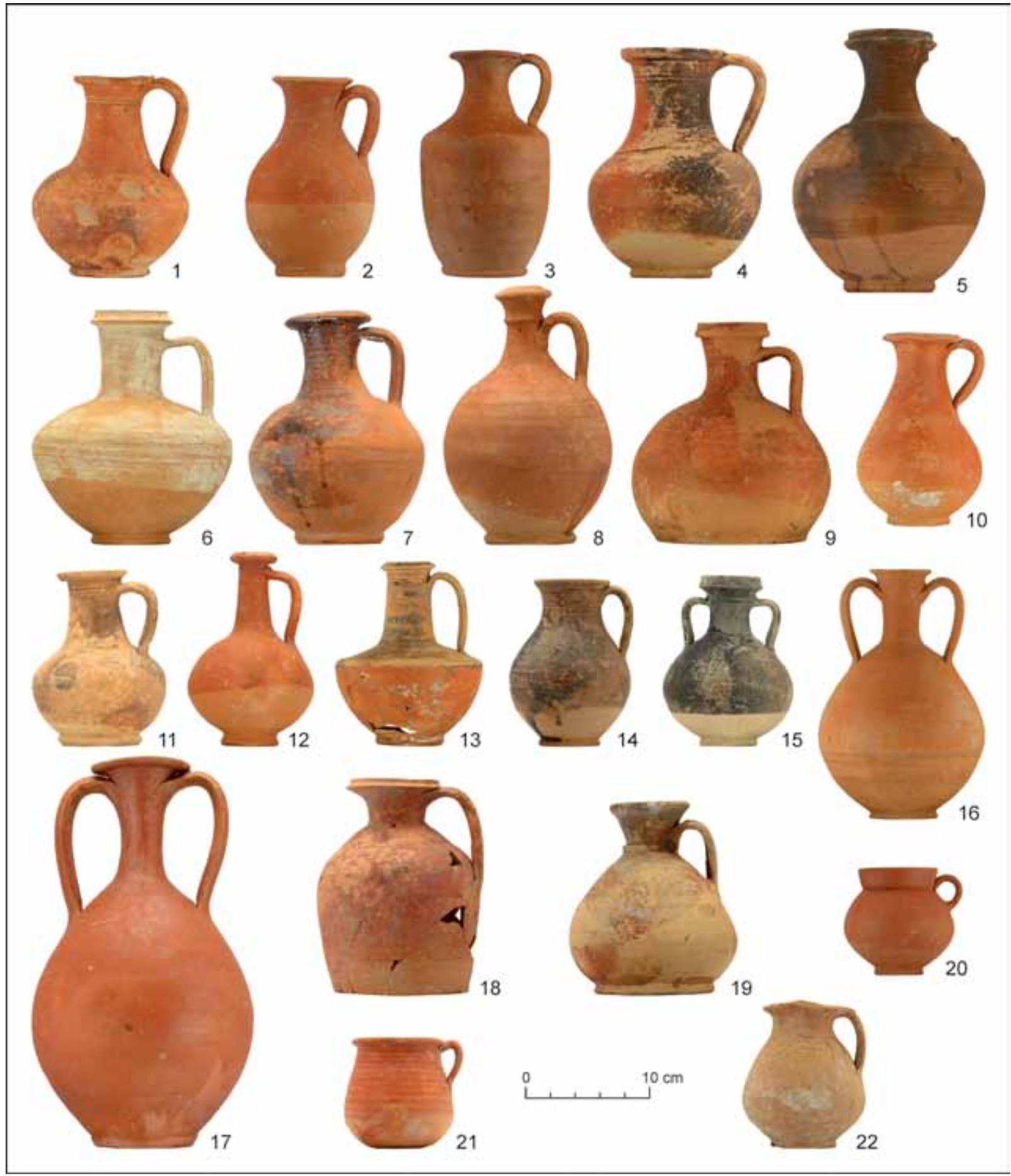

Fig. 4. The cemetery of Frontovoe 3. Red-slip pottery (pitchers, mugs, table amphorae, oenochoes). 1 - grave 183; 2 - grave 287; 3 - grave $5 ; 4$ - grave $329 ; 5$ - grave 201; 6 - grave $329 ; 7$ - grave $79 ; 8$ - grave 205; 9 - grave 313; 10 - grave 243; 11 - grave 293; 12 - grave 328; 13 - grave 162; 14 - grave 192; 15 - grave 292; 16 - grave 318; 17 - grave 300; 18 - grave 158; 19 - grave 96; 20 - grave 280; 21 - grave 108; 22 - grave 322.

Zhuravlev 2010, 23). If one accepts this attribution anyway, the said vessels would mark the graves from the late $1^{\text {st }}$ to the first half of the $2^{\text {nd }}$ c., meeting the spatial structure of the cemetery of Frontovoe 3 . The graves from period 1 and the transition period contained four red-clay wheel-made vessels with no slip covering: two unguentaria and two pitchers of various forms. In period 2, there were a gray-clay bowl and a pitcher with dark-gray surface. 


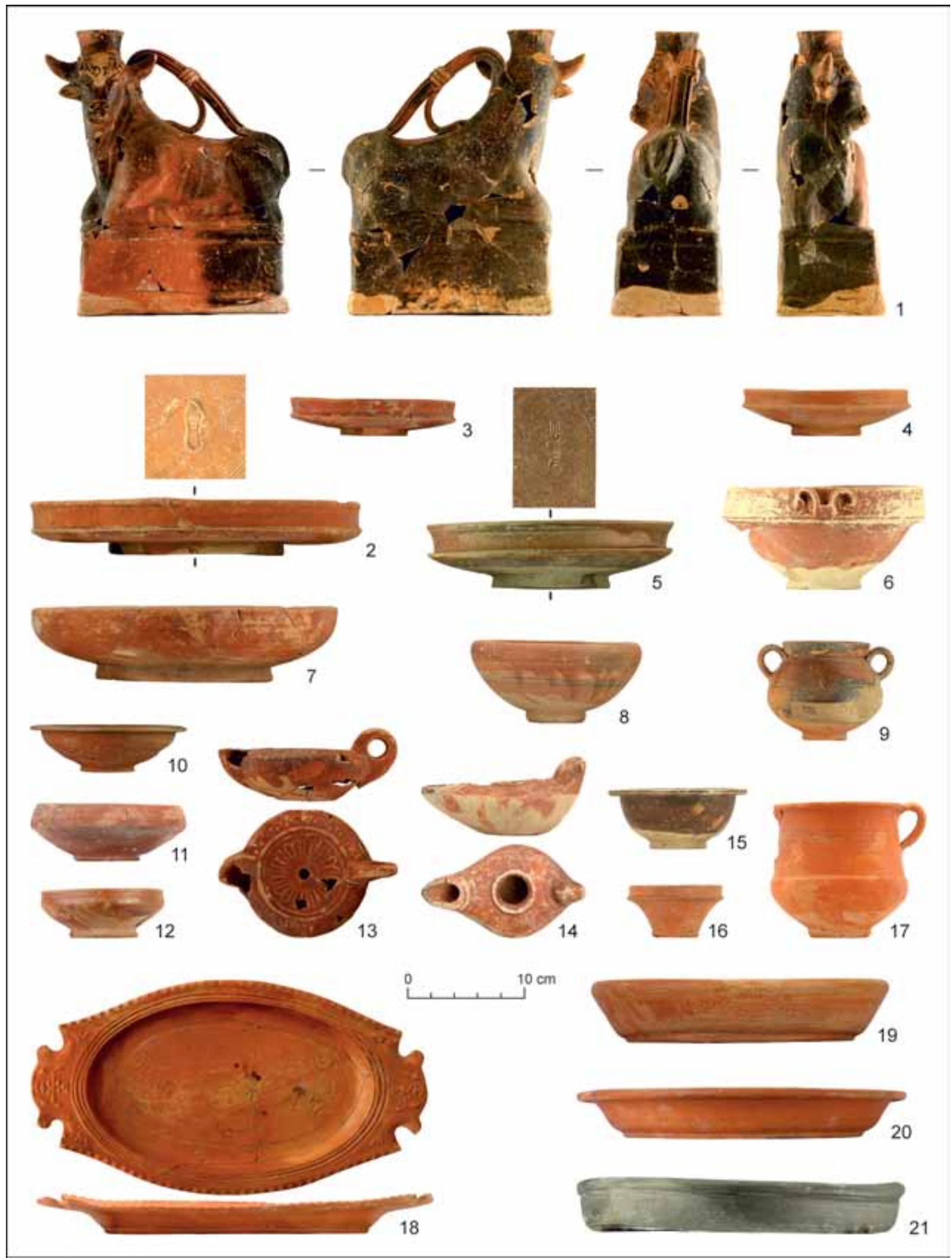

Fig. 5. The cemetery of Frontovoe 3. Red-slip pottery (other varieties) and a wheel-made vessel (21). 1 - grave 317; 2 - grave 320; 3 - grave 260; 4 - grave 227; 5 - grave 316; 6 - grave $304 ; 7$ - grave 292; 8 - grave 304; 9 - grave 278; 10 - grave 52; 11 - grave 104; 12 - grave 104; 13 - grave 323; 14 - grave 136; 15 - grave 297; 16 - grave 276; 17 - grave 111; 18 - grave 125; 19 - grave 137; 20 - grave $41 ; 21$ - grave 314. 


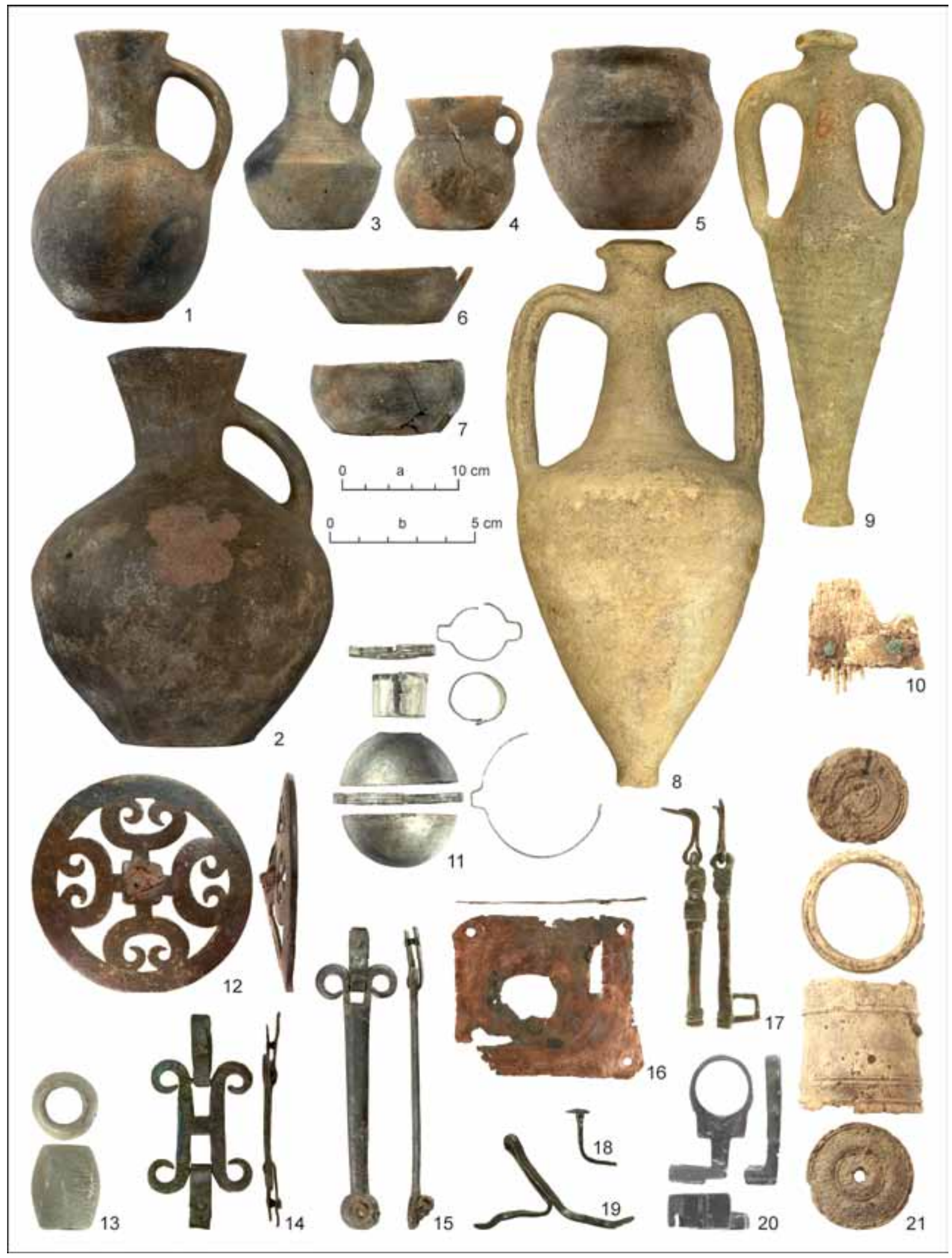

Fig. 6. The cemetery of Frontovoe 3. Hand-made vessels (1-7), amphorae (8, 9), comb (10), bottle fragments (11), clip bead (13), horse bridle parts $(12,14,15)$, casket fragments and keys (16-20), pyxis (21). 1 - grave 52; 2 - grave 205; 3 - grave 137; 4 - grave $154 ; 5$ - grave $52 ; 6$ - grave $178 ; 7$ - grave $96 ; 8$ - grave $170 ; 9$ - grave $136 ; 10$ - grave $6 ; 11$ - grave $106 ; 12,14$, 15 - grave 319; 13 - grave $41 ; 16-19$ - grave $151 ; 20$ - grave 232; 21 - grave 322 . Scale: a - 1-9; b - 10-21. 


\section{Hand-made vessels}

The excavations uncovered 109 hand-made vessels ${ }^{6}$. The forms of the hand-made ware from Frontovoe 3 meet with numerous analogies in synchronous sites in the south-western and sub-mountainous Crimea. Some of the types have been documented in the Crimea in the late Scythian period and later on (see e. g.: Dasherskaia 1991, pl. 10: 21; 11: 7, 13, 15; 12: 4; 14: 9; 16:16; 17: 4, 7, 8; 22: 1, 10; 27: 15, 18, 19; 52:11-18).

Period 1 is typical of handled bowls, pots with the maximum diameter at the top part of the body, and a fine pitcher which survived as the only specimen at Frontovoe 3. In graves from all the periods there were truncated-cone bowls (Fig. 6: 6) and pitchers with a high ovaloid body and a short neck (Fig. 6: 2).

All the other types of hand-made pottery ( $86 \%$ specimens) originate from the graves of period 2 . The most numerous among them are the pitchers of high proportions with a high narrow neck (Fig. 6: 1, 2) and those of low proportions with a short neck (Fig. 6: 2), truncated-cone and hemispherical bowls (Fig. 6: 6, 7), mugs with a globular body (Fig. 6: 4), and pots with a rounded biconical body and a short neck (Fig. 6: 5).

We have obtained the first results of the technological analysis of 40 specimens of hand-made vessels of period 2 of the cemetery. We have used the methods developed by A. Bobrinskii (1978) ${ }^{7}$, the founder of historical-cultural approach to the studies in the ancient pottery-making industry in the Soviet and Russian archaeology (Tsetlin 2012). This approach is based on the synthesis of archaeological and ethnographical data with scientific experiment. We are bearing in mind that the pottery products from the pre-industrial production level distributed mostly in the limits of the settlements where they were made. The skills of its making were transmitted as direct teaching of the family members with the techniques of clay working. The continuity of labour habits directly depended on the potters' cultural environment and the stability of this population. Adaptive labour habits, such as selection and mining of initial raw materials, the making of clay body, and the treatment of vessel surface, were especially sensible to the changes in cultural environment; they speedily changed in relation to the predominant tradition.

We have studied the samples with binocular microscope MBS-1. The attribution of the types of initial plastic raw materials, the determination of the clay body composition, and the documentation of different surface treatment techniques were made with account to the materials of the vast collection of experimental samples residing in the History of Ceramic Ware Laboratory in the Institute of Archaeology of the Russian Academy of Sciences (Moscow).

All the vessels from Frontovoe 3 under study were made of natural clay used in naturally-watered condition. At the stage of original selection of plastic raw materials for the making of pottery, there was one prominent tradition related to the use of poorly-sandy and medium-ferrous clays.

We have documented two ways of processing outside surface of the vessels. The first and the most popular was polishing; it has been documented on 34 vessels. According to the lack of furrowed grooves on vessel surface, the polishing was made on dry and preliminary slightly watered surface. The second technique of processing the outer surface is "soft" polishing documented at six vessels. There are two cases polishing with fingers and four cases of polishing with a soft material, possibly a thin textile according to the structure of its traces.

The analysis of clay body uncovered two popular recipes. 28 vessels were made of clay body with addition of grounded shells and liquid organics, and 11 vessels more of clay body with addition of grounded shells, liquid organics, and extra admixture of grog. One more vessel was made of pure clay without artificial additions. Interesting results were obtained from the comparison of these two recipes with various types of burial structures and specific vessels.

Firstly, almost all the artefacts featuring clay body addition of grit originated from burial vaults. This way, technological data document the appearance of a new population on the site, showing minor differences in the making of clay bodies.

Secondly, all the hand-made vessels featuring the clay body with addition of grit are high-proportioned pitchers with a high narrow neck (Fig. 6: 1, 3) or mugs with a globular body (Fig. 6: 4). Both handmade ware types do not meet with direct parallels among synchronous or earlier materials from the North Caucasus, the region connected to the origin of flat burial vaults of the south-western Crimea according to some colleagues (Aibabin 1994; Khrapunov 2002, 79, 80; 2004, 138, 139).

\footnotetext{
6 A series of observations on this group of finds has been stated in details in the forthcoming articles: Sukhanov, in press; Sukhanov/Sviridov/Yazikov, in press.

7 For the details on historical-cultural approach, see English publications: Tsetlin 2005; 2010; 2013.
} 
Therefore, the results of technological analysis of ceramics and their comparison with the forms of vessels testify to the weak role of the North Caucasus tradition in the shaping of the hand-made ware complex of the cemetery of Frontovoe 3. However, it is not possible to totally deny this possibility at present state of research. Conclusive ethnocultural interpretations of varied traditions in hand-made ware manufacturing require a large-scale comparative research of pottery-making techniques in different regions, such as the south-western, sub-mountainous, and southern Crimea, Bosporos and North Caucasus. So far we can only state that the population which created flat burial vaults at Frontovoe 3 had very similar traditions of pottery-making with those who buried there in undercut graves. The nature of the differences in clay body suggests that, even if the appearance of burial vaults in the cemetery of Frontovoe 3 was related not to the borrowing of the funeral rite but rather to the coming of a new group of persons, the newcomers were rapidly incorporated into the local community.

\section{Amphorae}

Among the other groups of pottery from the cemetery of Frontovoe 3, let us mention light clay late Herakleian amphorae. Their variant C IVD (Fig. 6: 8; according to Vnukov 2016) appeared in the assemblages from the late stage of period 1 and early stage of period 2, and variant C IVF (Fig. 6: 9) only in the assemblages from period 2.

\section{GLASS VESSELS}

The collection of glass vessels comprises ca. 230 specimens of various degree of preservation, from the completely preserved specimens to heaps of fine fragments. Most vessels are made of naturallycoloured glass in free-blowing technique. Only a few ones are manufactured of blue or manganese glass in mould-blowing technique. Bottoms of most vessels bear a pontil mark.

\section{Balsamaria}

Balsamaria (toilet bottles) constitute the most extensive group of glass vessels of period 1 (about 55 specimens; Fig. 7: 14-16, 18-19, 22-23), mainly of group 2 type I (according to Kunina/Sorokina 1972). Some vessels of this group occurred in a little bit later context.

\section{Vessels from the $1^{\text {st }}$ to the first half of the $3^{\text {rd }}$ century}

From the early zone of the cemetery some extraordinary glass vessels have come. Among them is a small greenish blue oenochoe decorated with spiral thread of opaque white glass of the late $1^{\text {st }}-2^{\text {nd }} \mathrm{c}$. (Fig. 7: 26). The mould-blown goblet with a cylindrical body (Fig. 7: 27) decorated with relief representations of "wreaths", palm fronds, and a Greek inscription "Take the victory" (the so-called "Victory" beaker) belongs to a group of $1^{\text {st }} \mathrm{c}$. vessels with Greek inscriptions: in the north Black Sea area about two dozens of fragments and complete vessels of this type have been found. Reverse writing of letter " $\mathrm{N}$ " in the article "THN" on the beaker from Frontovoe indicates its Syria-Palestinian provenance (Whitehouse 2001, 26).

The periphery of the early zone of period 1 (graves 232 and 304) has yielded the so-called ointment jars (form 68 after Isings 1957, 88, 89), including one of "cobalt" glass (Fig. 7: 24). There are analogous vessels excavated in Chersonese and Sovkhoz 10 cemetery (Strzheletskii et al. 2003-2004, 116, 119, pl. XXVIII: 20). L. Barkóczi assigns similar ointment jars to the second half/late first - early $2^{\text {nd }} c$. (Barkóczi 1988, 205, pl. LX: 514-518).

In grave 263 (the eastern zone of period 1) there was a bottle with muff-shaped rim typical of the vessels discovered in the Bosporan graves dated to the first half of the $1^{\text {st }}$-early $2^{\text {nd }} \mathrm{c}$. (Golofast 2006, 316). Of interest is an amphoriskos with relief ornamentation (Fig. 7: 25), which was blown in a mold with two vertical sections and made of glass of different colours: the body is formed of manganese glass and the handles of greenish one. The glass of two colours (deep blue for the body and light manganese for the handles) was used in the manufacture of a very close amphoriskos from the Corning Museum of Glass 


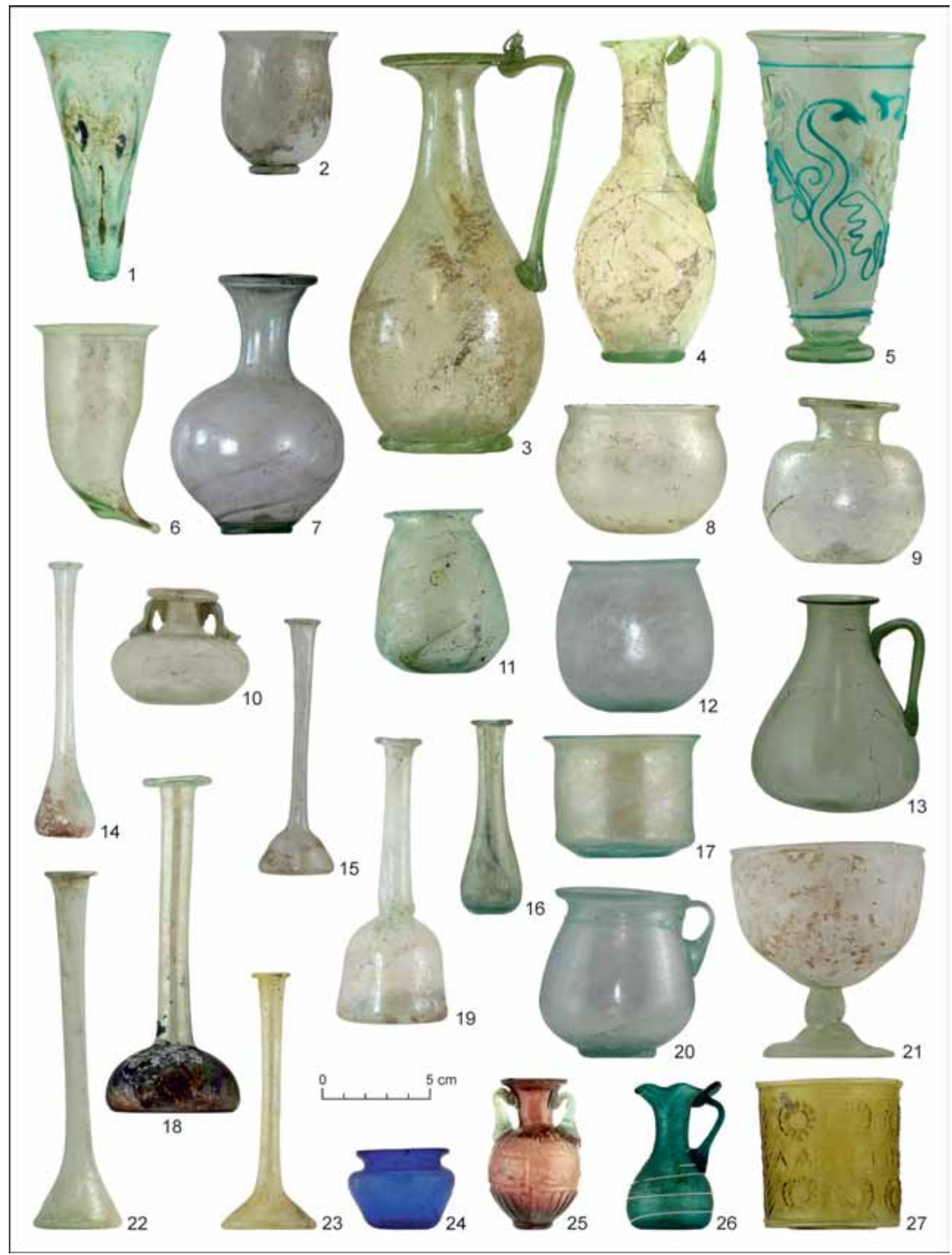

Fig. 7. The cemetery of Frontovoe 3. Glass vessels. 1, 2 - grave 51; 3 - grave 105; 4 - grave 89; 5 - grave $65 ; 6$ - grave 266; 7 - grave $46 ; 8,9$ - grave $85 ; 10$ - grave 202; 11 - grave $83 ; 12$ - grave $3 ; 13$ - grave $94 ; 14$ - grave 3; 15 - grave $62 ; 16$ - grave 298 ; 17 - grave 202; 18 - grave 286; 19 - grave $61 ; 20$ - grave $5 ; 21$ - grave $70 ; 22$ - grave $166 ; 23$ - grave $244 ; 24$ - grave $304 ; 25$ grave $263 ; 26$ - grave $304 ; 27$ - grave 319. 
(it can't be excluded that amphoriskoi from Frontovoe 3 and the Corning Museum were blown in one mould). Parallels to these two vessels originate from the assemblages dated to the second half of the $1^{\text {st }} \mathrm{C}$; such vessels are supposed to have been produced in the Eastern Mediterranean or Italy (Whitehouse 2001, 43).

Two vessels from the eastern and southern zones of period 1 (graves 166 and 284) are usually interpreted as drinking horns (Fig. 7: 6). However, L. Barkóczi identifies them as filtration flasks. The date of these vessels is determined within the $3^{\text {rd }}$ to early $5^{\text {th }}$ c.; yet some specimens have been uncovered in the assemblages of the $2^{\text {nd }} c$. (Barkóczi 1988, 126, 127).

The same zones have produced beakers with a cylindrical body, out-turned rim with rounded edge, and concave bottom (Fig. 7: 17), very popular in the northern Black Sea area. In Tanais and Pantikapaion, they came mostly from the assemblages of the second half of the $2^{\text {nd }}$-first half of the $3^{\text {rd }}$ c. (Sorokina 1962, 226, fig. 7: 2; 9: 8-10; 1965, 204, 205, fig. 1: 1-8).

The same area of Frontovoe 3 gave vessels with a bag-shaped body, out-turned rim with rounded edge, and concave bottom; several artefacts are decorated with applied thread of the same colour as the vessel itself (Fig. 7: 20). Vessels of analogous form and often with similar ornamentation were widespread throughout the Roman Empire in the $3^{\text {rd }}-4^{\text {th }}$ c. (Whitehouse 2001, 158-160, nos. 679-681). J. Hayes has dated them to the late $3^{\text {rd }}$-first half of the $4^{\text {th }}$ c. (Hayes 1975, 121, fig. 12: 475) but the finds from Frontovoe 3 testify to their earlier date.

Some rarely found in the Crimea forms are represented in the southern zone of period 1 . Among them is a thick-walled beaker from grave 65 (Fig. 7: 5). It has almost cylindrical body ornamented with ivy sprouts and leaves composed by applied white and turquoise threads ("snake-thread decoration"). These vessels were made in the $3^{\text {rd }} \mathrm{c}$. both in the eastern and north-western provinces of the Roman empire. In the Crimea, vessels decorated in this style are very rare. So far only two fragments from Chersonese have been published (Ryzhova 2003, 151-153, fig. 1: 1, 3). We failed to find exact analogy for the vessel with a broad hemispherical body and independently-made solid circular stem, to which a solid mushroom-shaped base was attached (Fig. 7: 21) though analogous stems were characteristic for the $2^{\text {nd }}-3^{\text {rd }}$ c. beakers with cylindrical body of form Isings-86 (Isings 1957, 103). The lower body of a painted vessel (wide gold strip between two thin lines in brown) with an analogous stem was discovered in the fire layer of the mid-3 ${ }^{\text {rd }}$ c. in Tanais (Arseneva/Naumenko 1992, 22, 63, fig. 94: 2).

Parallels to the single-handle cup from the southern zone of period 1 (Fig. 7: 20) have come from the assemblages of the $2^{\text {nd }}-3^{\text {rd }} \mathrm{c}$. uncovered in the Sovkhoz 10 cemetery and Bosporos (Strzheletskii et al. 2003-2004, 120, pl. XXVIII: 30). Grave 202 of the same zone has given an aryballos (form 61 after Isings $1957,78-81$; fig. 7: 10). Such bathing accessories were widespread in the Roman world in the mid- $1^{\text {st }}-3^{\text {rd }} c$., though after the $2^{\text {nd }} \mathrm{c}$. these vessels became less popular (Sorokina 1987, 40; Whitehouse 2001, 201). According to N. Sorokina's observations, the aryballoi close to the vessel from Frontovoe 3 by the rim form and the way of handles attachment were produced in the Mediterranean area in the $2^{\text {nd }}$ c. (Sorokina 1987, 43).

\section{Vessels from the $3^{\text {rd }}$ to mid- $5^{\text {th }}$ century}

In the burials of the final of period 1 and period 2 two types of beakers considerably prevail. Beakers with a rounded body, out-turned rim with rounded edge, and a pushed-in base (about 20 specimens; Fig. 7: 2) belong to I. Khrapunov's type I (Khrapunov 2002, 56), which are likely to have been produced in Chersonese (Belov 1965, 238, fig. 2: 3; 1969, 81, 83, fig. 23: a-B; Sorokina 1973, 187). ${ }^{8}$ The earliest vessels of this type originate from the cemetery of Belbek IV where they are dated to the period before the mid-3 ${ }^{\text {rd }}$ c. (Sorokina/Gushchina 1980, 93), a destruction layer of 240 AD in Gorgippia (Alekseeva/Sorokina 2007, 16, pl. 10: 2, 3, 5), grave 9 (35) in Chernorechenskii cemetery with the coins from the mid- $3^{\text {rd }} \mathrm{c}$. and grave goods from the second half of the $3^{\text {rd }} \mathrm{c}$. (Babenchikov 1963, 97-100, fig. 4: 9). In the $4^{\text {th }}$ c., they became the most popular type of glass ware among the barbarian population of the central and south-western Crimea and one of the most widespread type of glass vessels in the cemeteries of the sub-mountainous Crimea (Khrapunov 2002, 56). In the $5^{\text {th }}$ c., they came out of use; the argument is their absence in the cemeteries of Luchistoe and Skalistoe (Aibabin/Khairedinova 2008; 2014; Veimarn/Aibabin 1993).

8 Crimean beakers are usually incorrectly attributed to the form Isings-108, which characterized with a cracked-off unworked edge and a little bit different proportions (Isings 1957, 134). 
More numerous (about 25 specimens) are beakers of the second type with a globular body, abruptly out-turned rounded edge, and poorly pronounced solid ring-base (Fig. 7: 12). I. Khrapunov identified them as variant 2 of type II, to which he also assigned bowls with an analogous body but cracked-off edge and slightly concave bottom (Khrapunov 2002, 56, fig. 99: 8, 10) also represented in Frontovoe 3 (about 10 specimens). In the Crimea, the earliest grave containing a beaker of variant 2 of type II (Kharaks, grave 34) is dated to the second quarter of the $3^{\text {rd }}$ c. (Orlov 1987, 112-116, fig. 6: 3). From the mid- $3^{\text {rd }} \mathrm{c}$. into the $4^{\text {th }} \mathrm{c}$. both types in question coexisted (Khrapunov 2002, 56). This observation does not contradict to the materials of Frontovoe 3; of note is a complete absence of beakers of type II in the latest zone of period 2 where exclusively beakers of type I are present. In the area of transition to the medium zone of period 2 some other types of glass vessels were also found (Fig. 7: 7, 9).

Of interest are three jugs with a pear-shaped body, out-tuned rim with rounded (Fig. 7: 13; vessels from graves 92 and 94) or cracked-off (vessel from grave 91) edge, plano-covex-sectioned handle, and concave bottom ("jug-mugs" after Kunina 1997a, 70) that were found in the burials of the early zone and the adjoining part of the medium zone of period 2. We know only two similar vessels discovered outside the Bosporos, in the $4^{\text {th }}$ c. burials of the cemeteries of Neizats and Kilen-Balka (Khrapunov 2008a, 382, fig. 16: 2; 2011, 25, 26, fig. 20: 2; Shabanov 2015, 118). The concentration of analogous jugs in the Bosporus and their similarity to $3^{\text {rd }} \mathrm{c}$. clay Sarmatian vessels widely distributed in the same area allowed N. Sorokina supposing their manufacture in Pantikapaion and possibly in Tanais (Sorokina 1965, 217, 219, fig. 9; 1982, 41, fig. 7). In Tanais and Gorgippia, jugs of the type occurred in the destruction layer of the mid-3 ${ }^{\text {rd }}$ c. (Alekseeva 1997, 203, pl. 242: 5; 243: 7; Alekseeva/Sorokina 2007, pl. 72; Arseneva/Naumenko 1994, 104, fig. 27: 1; Sorokina 1965, 213, fig. 7: 6). The jugs discovered in Pantikapaion are also dated to the $3^{\text {rd }}$ c. (Kunina 1997b, 310, cat. nos. 278, 279; Sorokina 1965, 217, 219, fig. 9: 1-3). However, considering the finds from Neizats and Kilen-Balka, the period of their existence should be prolonged into the $4^{\text {th }} \mathrm{c}$. According to the materials of Frontovoe 3, their chronology does not extend beyond the period from the second half of the $3^{\text {rd }}$ to mid- $4^{\text {th }} \mathrm{c}$.

The medium zone of period 2 and adjoining areas have yielded pitchers (Fig. 7: 3, 4) widely distributed in the Crimea in the $4^{\text {th }}$ c. (Aibabin 1990, 13, 146, fig. 3: 11, 12; Shabanov 2011, 153-157).

Among the latest finds is a conical beaker with blue blobs (Fig. 7: 1), dating from the fourth quarter of the $4^{\text {th }}$ to the first half of the $5^{\text {th }}$ c. (Gavritukhin 2017, 101-103, 105; with bibliography).

\section{BEADS, NECKLACES AND PENDANTS}

The graves in Frontovoe 3 cemetery contained more than 15,000 beads and seed beads.

\section{Glass beads}

Glass beads are the most numerous group. There were monochrome beads of various forms: globular (Fig. 8: 2-4, 67), barrel-shaped, cylindrical (Fig. 8: 50), biconical (Fig. 8: 10, 24), ribbed globular (Fig. 8: 8, 12), flattened disc-shaped (Fig. 8: 28, 29), 14-hedral (Fig. 8: 13); there also were polychrome beads with applied decorations (Fig. 8: 51-54) and glass shard beads of various forms (Fig. 8: 14, 48, 49, 79). There also were many seed beads, featuring globular and cut (not fused) cylindrical forms (Fig. 8: 11, 66).

\section{Amber pieces}

Amber pieces are the second-in-number group featuring various forms: disk-shaped (Fig. 8: 9, 30, 34, 35, 38, 39), flattened oval (Fig. 8: 32, 33, 37, 40, 41). It should be mentioned that the graves from period 2 (mid- $3^{\text {rd }}$ to the early $5^{\text {th }}$ c.) contained mushroom-shaped, or as they are sometimes called the figure-ofeight-shaped, pendant beads (Fig. 8: 44). The bulk of these beads in closed assemblages from the Crimea dates from the second half of the $3^{\text {rd }}$ and especially to the $4^{\text {th }}$ c. Nevertheless, the earliest finds of mushroom-shaped amber pendant beads have been documented in burial vault 720 at the Late Scythian cemetery of Ust-Alma. According to imported Roman vessels, this vault dates from the middle or the third quarter of the $1^{\text {st }}$ c. (Mastykova 2016, 176-178, fig. 2; 3). 


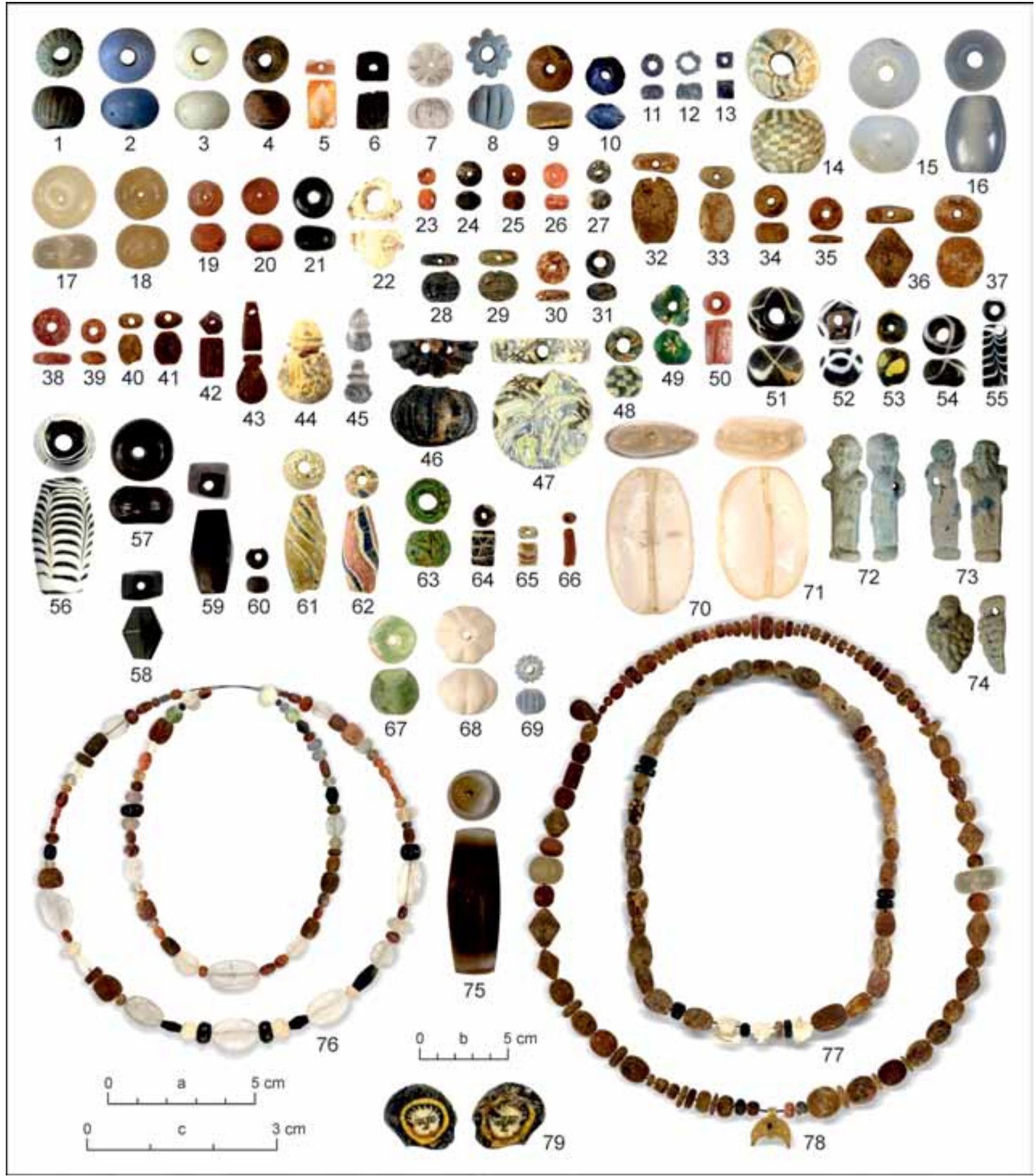

Fig. 8. The cemetery of Frontovoe 3. Beads and necklaces. 1 - 4 - grave 33; 5 - grave 89; 6, 7 - grave 327; 8 - grave 31; 9 , 10 grave $13 ; 11-13$ - grave $174 ; 14,15$ - grave $63 ; 17-20,23-27,34-43,78$ - grave $300 ; 21$ - grave $287 ; 22$ - grave $236 ; 28-31$ grave $95 ; 32,33$ - grave $236 ; 44$ - grave $22 ; 45$ - grave $327 ; 46$ - grave $19 ; 47$ - grave $123 ; 48$ - 50 - grave $128 ; 51,55,56$ - grave $8 ; 52$ - grave $59 ; 53$ - grave $96 ; 54$ - grave $236 ; 57-60,67-71,76$ - grave $205 ; 61,62$ - grave $318 ; 63$ - grave $238 ; 64$ - grave $123 ; 65$, 66 - grave $202 ; 72-74$ - grave $327 ; 75$ - grave $325 ; 77$ - grave $236 ; 79$ - grave 75 . Scale: a - $1-75 ; b-76-78 ; c-79$.

\section{Jet-stone beads}

Jet-stone beads are mostly globular, including spool-shaped (Fig. 8: 21, 57), elongated cylindrical, prism-shaped, 14-hedral with circular designs (Fig. 8: 6), bi-pyramidal (Fig. 8: 58, 59), and a number of cylindrical seed beads. 


\section{Carnelian beads}

Carnelian beads are mostly small globular (Fig. 8: 19, 20, 26) and ellipsoid (Fig. 8: 23); there also are flattened polyhedral pieces with cut corners (Fig. 8: 5).

\section{Rock crystal beads}

Rock crystal beads were widespread in the graves from the $1^{\text {st }}$ and $2^{\text {nd }} c$. (period 1). Most of them are big, flattened oval, featuring two-side drilling (Fig. 8: 70, 71); there also are circular and ribbed pieces (Fig. 8: 7).

\section{Chalcedony beads}

Chalcedony beads of circular forms are a few in number, mostly featuring light blue, smoky, and yellowish colours (Fig. 8: 15-18).

\section{Agate beads}

Agate beads are represented bya few small prism-shaped and ellipsoid pieces and one big cylindrical piece (Fig. 8: 75). Generally, the beads discovered from the cemetery of Frontovoe 3 are known from the sites in the northern Black Sea area which dated from the Roman period, such as Pantikapaion, Phanagoreia, Druzhnoe, Neizats, Chersonese, Sovkhoz 10, and others (Khairedinova 1995; Stoianova 2004). The preservation of the graves allows the one to discover the dynamics of changes in bead sets according to the chronological periods of the cemetery. The biggest number of varied beads appeared in graves from period 1 (late $1^{\text {st }}$ to the first half of the $3^{\text {rd }} \mathrm{c}$.). In period 2 of the cemetery (mid- $3^{\text {rd }}$ to early $5^{\text {th }} \mathrm{c}$.), especially near its final, the number of beads in graves declined, and the necklaces showed less impressive variety of colours and materials. The types of beads changed, and some of them disappeared, such as complicated glass shard pieces, but there appeared new types, such as polyhedral (the so-called 14-hedral; Fig. 8: 13), which were widely distributed throughout the Eastern European Barbaricum throughout the Roman period (Mastykova 2009, 106-108). Taking the aforementioned fact into account, there are reasons to suppose cultural innovations and the changes in connections of the population that created the cemetery of Frontovoe 3.

We have documented necklaces comprising several threads of beads, often with various pendants (Fig. 8: 76-78).

\section{Pendants}

In the early zone of period 1 of the cemetery of Frontovoe 3, there were assemblages with gold pendants decorated with filigree, granulation, and tone and glass insets. For example, there are lunula pendants, sometimes richly adorned (Fig. 9: 2) or having knobs at the ends and near the loop (Fig. 9: 3). Among the finds there are four cylindrical amulet-cases with loops for hanging, mostly with closed butts and decorations richer than that of lunula pendants (Fig. 9: 6). The relatively big, plain, not decorated amulet-case from grave 301 had open butts and contained two human finger bones. Various pendants with gold cylindrical tubes form a magnificent necklace discovered in grave 208 (Fig. 9: 23). Two pendants from grave 287 depict a bust of a female goddess with Eros' head on one side (Fig. 9: 1).

In period 1 (late $1^{\text {st }}$ to the first half of the $3^{\text {rd }} \mathrm{c}$.) and the early period 2 (second half of the $3^{\text {rd }} \mathrm{c}$.) there often were silver and bronze pendants forming a part of necklaces: lunula pieces with twisted ends (Fig. 9: 4); hemispherical and pyramidal bells (Fig. 9: 12); openwork, knobbed and ring-shaped, wheel-shaped (Fig. 9: 17, 18); cone- and amphora-shaped (Fig. 9: 7-10), and others. There are pierced coins with the hole for wearing and their imitations. There occur figural pendants of bone, horn and faience. 


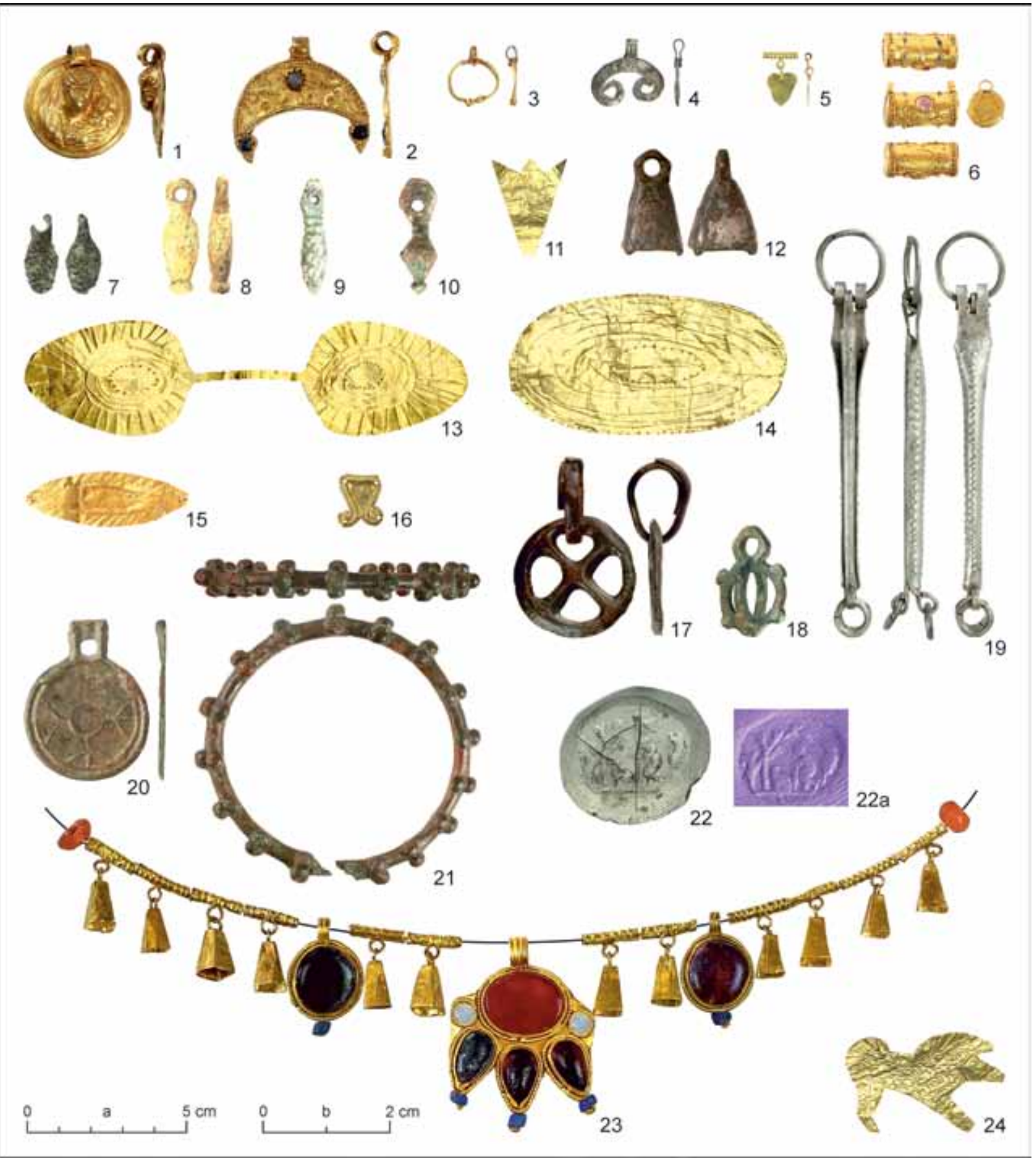

Fig. 9. The cemetery of Frontovoe 3. Pendants, appliqués, glass inset and its plaster-cast (22, 22a). 1, 2 - grave 287; 3 - grave 205; 4, 8 - grave 33; 5, 16 - grave 312; 6 - grave 300; 7 - grave 273; 9 - grave 240; 10 - grave $8 ; 11,24$ - grave 317; 12,17 - grave 257; 13,14 - grave 313; 15 - grave $36 ; 18$ - grave 112; 19 - grave $6 ; 20$ - grave 21; 21 - grave 319; 22 - grave 141; 23 - grave 208. Scale: $\mathrm{a}-1-21,23 ; \mathrm{b}-22,24$.

\section{EARRINGS, BRACELETS AND FINGER-RINGS} $1-5)$.

There are about 150 specimens of earrings. The types with a loop-and-hook lock predominate (Fig. 10:

In the earliest zone (chronological "core") of the cemetery there were three pairs of gold earrings. The first pair had the lock of a simple wire, which held a perpendicular narrow pendant with three rod-shaped appendages having slightly curved and hammered ends (Fig. 10: 14). Unfortunately, the 


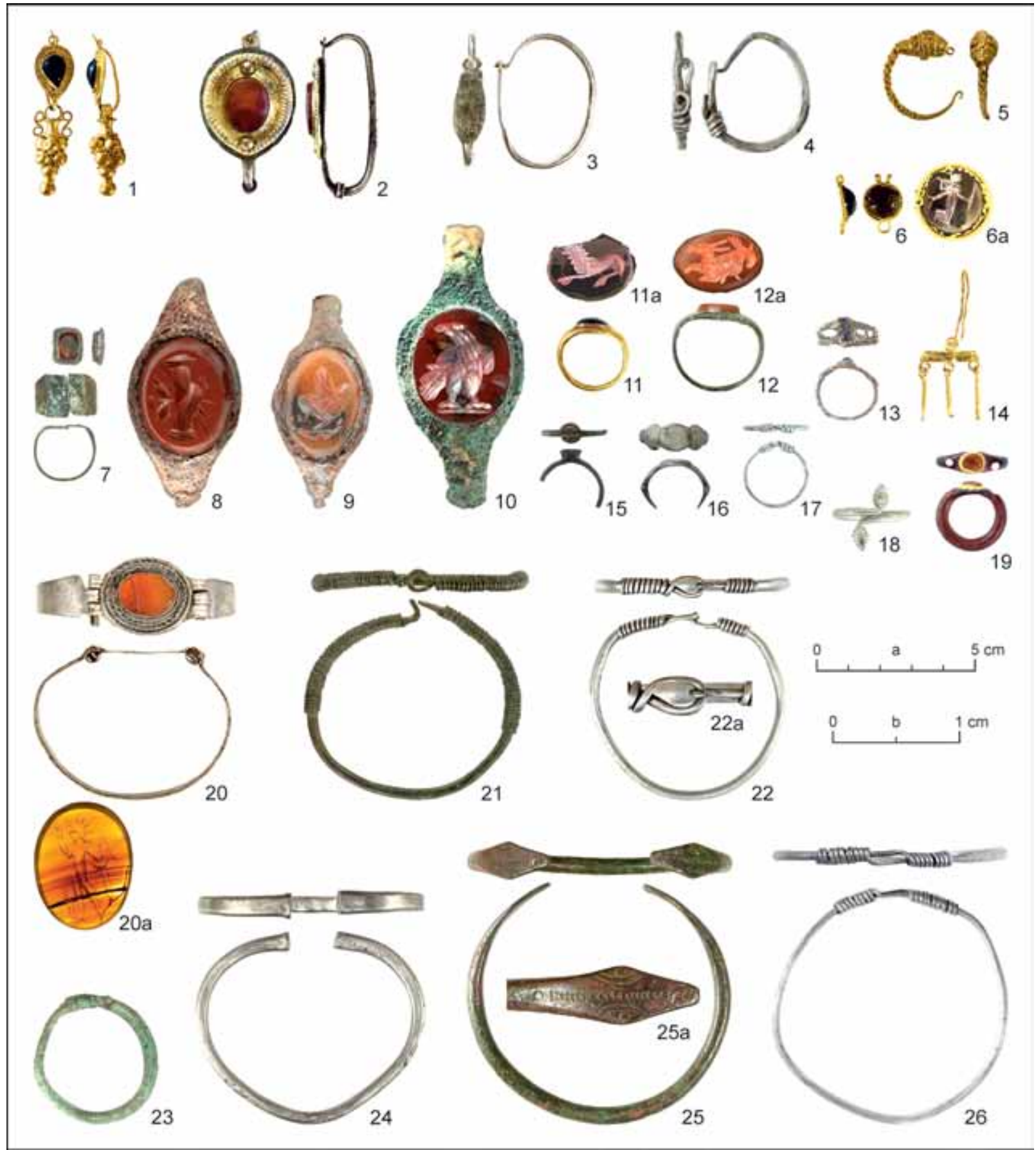

Fig. 10. The cemetery of Frontovoe 3. Earrings, finger-rings, bracelets. 1 - grave 136; 2 - grave 16; 3 - grave 13; 4 - grave $27 ; 5,6$ - grave $312 ; 7$ - grave $3 ; 8,9$ - grave $232 ; 10$ - grave $60 ; 11$ - grave $300 ; 12$ - grave 184; 13 - grave $234 ; 14$ - grave 320; 15 - grave 154; 16 - grave 33; 17 - grave 158; 18, 21 - grave $21 ; 19$ - grave $230 ; 20$ - grave 145; 22 - grave 85; 23 - grave 78 ; 24 - grave $17 ; 25$ - grave $234 ; 26$ - grave 75 . Scale: a - 1-7, 11-26; b - 8-10.

things which were fastened to the rods of these earrings remain unknown. The second pair has braided loop with a bulge in the form of lion's head (Fig. 10: 5). Their lock possesses a disk-shaped appendage (Fig. 10: 6) with a convex inset, one decorated with incised image of a stepping figure wearing long cloths and holding a spear and a shield (Fig. 10: 6a). The earrings with a bulge shaped like lion's head reveal the continuation of the Hellenistic tradition in the Early Roman period. The third pair of earrings (grave 300) resembles the second, though it does not have the ending in the form of lion's head and disk-shaped appendage to the lock. 


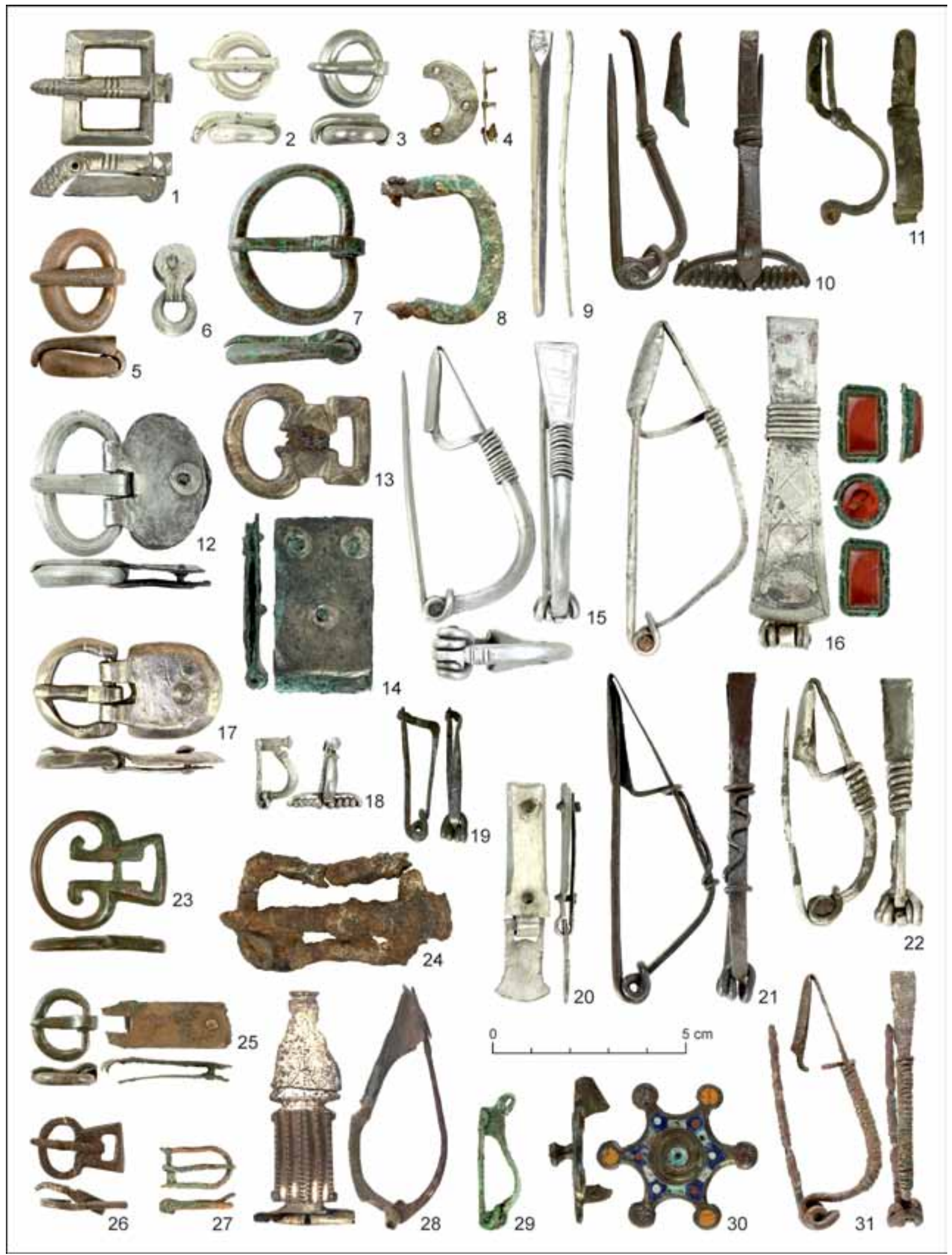

Fig. 11. The cemetery of Frontovoe 3. Brooches, buckles, belt-fittings and strap-ends. 1, 2 - grave 178; 3, 4, 9 - grave 172; 5 - grave 136; 6 - grave $52 ; 7$ - grave $16 ; 8$ - grave $20 ; 10$ - grave $94 ; 11$ - grave $175 ; 12$, 14 - grave $94 ; 13$ - grave $45 ; 15$ grave $9 ; 16$ - grave 106; 17 - grave $9 ; 18$ - grave 13; 19 - grave $62 ; 20$ - grave $3 ; 21$ - grave 69; 22 - grave 3; 23 - grave 112; 24 - grave 199; 25 - grave 170; 26 - grave 233; 27 - grave 326; 28 - grave 287; 29 - grave 234; 30 - grave 200; 31 - grave 170. 
Other earrings from period 1 are simple, often having the lock's loop decorated with a scroll, where the winding of a part of the body started (Fig. 10: 4). In grave 10 (the southern zone of period 1, at the junction with the early zone of period 2) there was a small earring of the type with two scrolls, made of gold. In the latest zones of period 1 and early zone of period 2, apart from the above-described pieces, there also were earrings of analogous pattern but, instead of the scroll, with a small panel at the lock, as a rule showing an applied inset or its traces (Fig. 10:3).

In period 2, especially demonstrative were rather big earrings with the panel decorated with a guilt plate featuring impressed ornamentation and a red, or rarely blue inset (Fig. 10: 2). In grave 136 (the medium zone of period 2), there was a pair of such earrings made of gold, showing a blue glass inset and a pendant in the form of a stylised amphora with a bunch-of-grapes-shaped body (Fig. 10: 1).

The collection of Frontovoe 3 possesses about 150 bracelets. $^{9}$ A great part of them has free thickened ends (Fig. 10: 24). In the assemblages from period 1 there often were bracelets with ends widened as stylised snake's heads (Fig. 10: 25); many bracelets belonged to a few variants with the ends tied (Fig. 10: 26), including those featuring a complicated knot, or the beads put on bracelets; there are a few pieces with drop-shaped or figural bulge (Fig. 10: 23) on the ends, with winded body, and so on. There is a series of bracelets from periods 1 and 2 with the lock of the pattern used in the most earrings (Fig. 10: 21, 22). In period 2, there appeared plated and hinged bracelets with the panel decorated with a framed inset, usually of carnelian and in one case with engraved gemstone (Fig. 10: 20). The bracelet from grave 205 (the southern zone of period 1) has such a panel fastened with hooks and not with a hinge.

The finds include about 200 finger-rings, mostly flattened, with widening ends which held a socket with an inset. The insets resembling hemisphere, often made of glass, are more typical for period 1 , and the flattened pieces, often made of carnelian (Fig. 10: 7), for period 2. In some cases, there are insets of engraved gemstones (Fig. 10: 8-12).

The most varied are the finger-rings from period 1, with tied ends, in parallel to some bracelets (Fig. 10: 17); with paired hoops and insets, and openwork wire decorations (Fig. 10: 13); with a circular polychrome inset; with free ends shaped as paired scrolls or a crawling snake (Fig. 10: 18, etc.); with a plated panel, sometimes engraved; bread-shaped, with the ends going beyond each other (grave 212). Apart from metal pieces, it is worth mentioning a glass polychrome finger-ring (Fig. 10: 19) from the eastern zone of period 1 .

Among the finer-rings from period 2, apart from the above-mentioned composite pieces, there were cast artefacts, including those with a socket for an inset or with incised decoration which could be used as a signet-ring (Fig. 10: 15), of complicated forms (Fig. 10: 16).

Generally, the set of earrings, bracelets, and finger-rings meets with a wide range of analogies in the sites of the sub-mountainous and south-western Crimea. In Frontovoe 3 there were a very few specimens of the types which were rare or absent at the above-mentioned sites. It is demonstrative that the set in question is comparatively rich, featuring an impressive group of gold artefacts and a relatively big number of engraved gemstones used as insets.

As it has already been stated, there are cases when the bracelets feature the same construction as finger-rings and earrings discovered in the same graves or in the same zone. By all appearance, these finds represent the sets of the same style.

Especially impressive were polychrome sets of period 2, which has been repeatedly addressed by researchers (for a review of the analogies see: Khrapunov 2018; Khrapunov/Stoianova 2018). They usually comprised earrings, bracelets, and finger-rings (Fig. 10: 2, 7, 20). In the cemetery of Opushki in the sub-mountainous Crimea, there was a lunula pendant featuring the same style (Khrapunov 2018, fig. 10: 4). The brooch discovered in Frontovoe 3 (Fig. 11: 16) actually fits in with the set under analysis. Although the earring from grave 136 (Fig. 10: 1) is made of gold and not gilded as usual, it is relatable to the same style. The main period of existence of the ornaments of the kind was from the second half of the $3^{\text {rd }}$ to the first half of the $4^{\text {th }}$ c. Moreover, Frontovoe 3 and some other sites supply the prototypes to many basic elements of this attire, allowing the ones to suppose their shaping in the south-western and possibly sub-mountainous Crimea against the local background and, certainly, with a certain outside influence.

\footnotetext{
9 In some cases, the finds are much fragmented. Therefore, some of the fragments may belong to the artefacts other than
} bracelets. Our further research foresees the clarification of their attribution. 


\section{BROOCHES AND BUCKLES, STRAP-FITTINGS AND STRAP-ENDS}

\section{Brooches}

There are at least 350 brooches of different state of preservation. The most of them belong to the socalled violin-bow-shaped type (Fig. 11: 19), of the group Ambroz-14 or Hellström-I.1 (Ambroz 1966; Hellström 2018 $)^{10}$, sometimes occurring as a few pieces within the same assemblage. They are common for period 1 and also appeared in period 2 .

The earliest brooches of narrow chronology are single-piece bow-shaped brooches with a returned foot (Ambroz-15-I) of variant 2 (Hellström-IB.1c), early variants of fine brooches with a knob or a scroll (Fig. 11: 29) on the end of the solid catch-plate (Ambroz-12 and 13; Hellström-IC.1-2), and a hinged arcbow-shaped brooch with a solid catch-plate (Ambroz-5; Hellström-VB.2). At the junction of the early and eastern zones of period 1 of the cemetery in question, there were bow-shaped brooches with a returned foot (Ambroz-15-I) of variant 3 (Hellström-IB.1d) and a Roman brooch (Fig. 11: 28) of M. Feugere's type 23a (Feugère 1985). In the assemblages from period 1, there were at least six Roman enamelled plate brooches (Fig. 11: 30), mostly of geometric or zoomorphic forms.

In the latest zones of period 1, there were typical single-piece bow-shaped brooches with a returned foot (Ambroz-15-I) of variants 4 (Fig. 11: 31) and 5 (Hellström-IB.1e.1), though the so-called Inkermantype finds predominated (Ambroz-15-II; Hellström-IB.1e.2/III.1a). The latter are diverse (Fig. 11: 21), and their collection from Frontovoe 3 is the most representative of all known so far. Generally, the set of brooches from period 1 is quite typical for the northern Black Sea sites.

In the early zone of period 2 of the cemetery in question, two-piece bow-shaped brooches with a returned foot predominated (Fig. 11: 22; Ambroz-15-III; Hellström-III.1b); at the junction of the zones of periods 1 and 2 there were cases when they combined with the Inkerman-type pieces in the same assemblage (Fig. 1: $f, g$ ). Among the rare forms of two-piece bow-shaped brooches, there are artefacts with winding around the body, a feature typical at early single-piece bow-shaped brooches; brooches with the axis of the spring fastened by a vertical stand (Fig. 11: 15), reflecting the influence of the brooches typical of the Cherniakhov and other cultures of the "East Germanic" circle (see below); brooches with a wide body decorated with incised lines and carnelian insets (Fig. 11: 16), stylistically resembling the local polychrome attire, which has already been discussed in relation to the earrings, bracelets, and finger-rings.

In the early zone of period 2, there also was a fine single-piece highly-profiled brooch (Fig. 11: 18). Its parallels are widely distributed in the North Caucasus and in the east of European steppe, and also penetrated to the population that established contacts with the said areas (Ambroz-11-II-3; see also: Gavritukhin 2010). Simultaneously, in Frontovoe 3 and some other Crimean sites there appeared twopiece brooches with a curved arched bow (P-shaped) and a returned foot (Ambroz-16/2-I) of variant 2 (Fig. 11: 10), which were typical of the cultures of the "East Germanic" circle.

From the latest part of the early zone of period 2 on, there occurred the brooches Ambroz-16/2-I variant 3 , featuring the same tradition as the above-mentioned variant 2 , and stylistically close brooches with a curved arched bow, a returned foot, and a wide ring holding the axis of the spring (Fig. 11: 11; Ambroz-16/3-I). The latter could come to the Crimea from the North Caucasus or from the eastern areas of the European steppe where they developed as a synthesis of two-piece bow-shaped brooches and brooches with a curved arched bow and a returned foot of the "East Germanic" circle (Gavritukhin/ Astafev/Bogdanov 2019, 177-179). Although both types appeared in Frontovoe 3 and other Crimean sites, the shaping of the brooches with a curved arched bow, a returned foot, and a wide ring holding the axis of the spring reside has been documented with certainty only in the eastern areas mentioned above. An alternative variant of penetration of these brooches into the Crimea, from the north-western Black Sea area, is also possible (e. g. Diaconu 1971, fig. VIII: 6-10; IX: 3, 10, 11).

\footnotetext{
10 Although many researchers use the typology and terms suggested by A. Ambroz (1966), there also are alternative systems. In this study we use the alternative names of the types according to a recent generalizing research of the northern Black Sea brooches as long as the $3^{\text {rd }}$ c. (Hellström 2018), which corresponded to period 1 and early period 2 of the cemetery of Frontovoe 3. For the translation, A. Ambroz's Russian terminology has been adopted to the English language using the terms suggested by $R$. Hattatt (1989).
} 


\section{Belt fittings}

The excavations uncovered around 200 belt fittings of various states of preservation (including about 50 iron buckles). In the zones of period 1, predominant types were the buckles and fittings of the Late Antique circle, mostly openwork buckles (known under key-hole form and other names; Fig. 11: 23, 26, etc.; Oldenstein 1977, 214-217, nos. 1002-1007, 1011-1014). They were widely distributed in Chersonese (Kostromichev 2015), the Roman stronghold in the Crimea located relatively close to the cemetery of Frontovoe 3. The buckles of this group also appeared in the assemblages from period 2 (e. g. Fig. 11: 13).

In period 1, there also were demonstrative finds of widely distributed in the European Barbaricum buckles of the type 13/14 of group A (Fig. 11: 24) and group D (Fig. 11: 27; according to Madyda-Legutko 1986), Eastern European buckles (Fig. 11: 25) of type П1, strap-ends resembling the type H3a (Malashev 2000).

There are typical to the south of Eastern Europe strap-ends of the types H7 (Fig. 11: 20), buckles of the types $\Pi 2 \sigma$ (Fig. 11: 17) and $\Pi 7$ (according to: Malashev 2000), and similar pieces with the tongue decorated with faceting, but without a ledge on the back side (such as Fig. 11: 12). They were discovered in the zones of the latest part of period 1 and early period 2. In grave 20, the buckle of the kind occurred along with a buckle which was rare in synchronous Crimean sites (Fig. 11: 8) and resembled type 29 of group D (according to Madyda-Legutko 1986). In this period, there appeared the strap-ends with a cordon on the end, which existed also in later times (Fig. 11: 14). There also were the buckles of the Late Roman cultural circle (Fig. 11: 7).

In the assemblages of the final zone of period 2 on, predominant types were the buckles $\Pi 9$ and $\Pi 10$ (Malashev 2000) of different variations (Fig. 11: 5, etc.). Analogous buckles featuring the tongue going round the frame farther than a half of its height (type П11 according to Malashev 2000) and rings on clips (Fig. 11: 6) appeared only in the medium and later zones of period 2.

Among the buckles of the type $\Pi 11$ there is variant $\Pi 11 \sigma$ featuring a characteristic tongue going round the front frame along its full height (Fig. 11:3), which marked the latest zone of period 2 and the cemetery in general. These buckles appeared both in Eastern and Central Europe in no earlier than the 370s (Gavritukhin 2010, 55; 2018, 49, 50; Malashev/Gadzhiev/Iliukov 2015, 100). C-shaped appliqués and sword-shaped strap-ends of other than early variants of the type in question (Fig. 11: 4, 9) are also demonstrative for the latest period of the cemetery of Frontovoe 3. They date to the same period according to the analogies in possession ( $A i-$ babin 1990, 50, 51; Bezuglov/Iliashenko 2000, 96, 97; Gavritukhin 2018, 94; Khrapunov 2008b; Malashev/Gadzhiev/ Iliukov 2015, 100; Tejral 2011, 289). These details of belt sets and a conical glass cup with blue applications (Fig. 7: 1) determined the calendar date of the latest zone of period 2 of the cemetery of Frontovoe 3.

In the latest zone of period 2 of Frontovoe 3, there was an iron oval buckle, very elongated vertically. In the Roman Danube area, the buckles of the type (Keller 1971, fig. 25: 1) appeared from the $4^{\text {th }}$ c. on, but in the Crimea they occurred much later, possibly from no earlier than the third quarter of the $4^{\text {th }}$ c. (Aibabin/Khairedinova 2017, 54; Iurochkin/Trufanov 2007, Chronological marker "ХИ" 47).

Grave 178 contained the buckles of the latest types. Two buckles (Fig. 11: 2) belonged to a widely distributed "trunk-shaped" type which was typical of stage D2 (380/400-440/450 AD) and a later period. Another buckle (Fig. 11: 1) dates from no earlier period, featuring a rare type which, paradoxically, was known from Britain to Kazakhstan (Bisembaev et al. 2018, fig. 5; Kazanski 2019a). Moreover, there are parallels to some elements of these buckles in the Crimea (Aibabin 1990, 29, fig. 23: 3-5; Aibabin/Khairedinova 2017, fig. 77; 78: 2, 3). These finds originate from the only grave in the cemetery of Frontovoe 3, located at its south-western extremity, thus determining the date when it ceased to be used about the early $5^{\text {th }} \mathrm{c}$.

\section{WEAPONRY AND HORSE TACK}

The graves from no later parts of period 1 contained 15 long swords ${ }^{11}$ without cross-guards; in grave 301 (the early zone), there was a sword put into a gold-plated scabbard. Grave 280 (at the western periphery of the northern area of period 1 , dating from the $2^{\text {nd }} c$.) contained central- and end-plates of a composite bow. Although such swords and bows were common among the steppe nomads, the settled peoples who contacted with the nomads also used these weapons.

Weapons are not typical for the central cemetery area. In the latest zones, weapons comprised spatha swords without cross-guards, an axe, a spear head, and the so-called daggers with cuts at the shoulders

\footnotetext{
11 Along with the greatest part of iron artefacts, the weapons are of very bad preservation; a more detailed characteristics of this group of finds will be available when the restoration finished.
} 
of the blade. The latter pieces (for the review and bibliography see: Radiush 2014) were no less than 10 in number. They were located near the shoulder/head, with the handle oriented to the legs. There were three cases when the persons buried with this weapon had a big bronze clip at their feet (Fig. 6: 13) keeping remains of wood; therefore, this weapon could be reconstructed as a pole arm. In vaults 41 and 136 (from the final of the early and medium zone of period 2) there were shield handles and bosses suggesting that the shields were leaned on the wall.

There are no less than 14 cases of iron ringed two-piece horse-bits, sometimes with bronze strap clips, laying near the dead persons. The horse tack is related to some of the buckles (see above). Let us mention a bridle from grave 319 from period 1, comprising cheek-pieces, paired strap-dividers, and pendants or fasteners of the bridle (Fig. 6: 12,14,15). These cheek-pieces meet with the closest parallel as a pair of the finds from Chersonese (Kostsiushko-Valiuzhinich 1901, 119, fig. 19), ${ }_{1}^{12}$ and the pendants as the find from Kotluban, where the Don comes close to the Volga (Skripkin 1989, fig. 1: 6, 7). Similarly to the weapons, horse tack is not typical of the central cemetery area.

Knives and their fragments, often with remains of wooden handles, were discovered almost in every grave. As a rule, they were located at an animal's bone and ceramic vessels at the dead person's head. There are several cases when remains of a scabbard occurred at the knife, sometime with a hanging loop.

Generally, the set of weapons and horse tack represented in Frontovoe 3 fits the range known from other synchronous sites in the Crimea.

\section{CASKETS, MIRRORS, PYXIDES AND OTHER ARTEFACTS}

Period 1 and the early period 2 were typical of caskets represented by bronze and iron parts, locks, keys, etc. (Fig. 6: 16-20).

There are no less than 24 mirrors of two types (according to Khazanov 1963), which are common in other cemeteries in the Crimea. Disk-shaped mirrors measuring up to $8 \mathrm{~cm}$ in diameter (type VI) occurred mainly in early assemblages from period 1. Mirrors of smaller size, with a side projection with a hole and decoration on the back side (Fig. 9: 20) of type IX, coexisted for a certain period with type VI, predominated in the latest zones of period 1, and also occurred in the early zone of period 2.

Mainly in the early zones, there were five bone pyxides, including those containing pink powder (Fig. 6: 21). In graves from period 1, there appeared no less than 45 bronze needles. In seven assemblages of the same zones there were devices hanged on rings (the so-called needle-cases), composed by a tube rolled up of a plate, which entered a half-opened case also rolled up of a piece of metal. Their curved ends held rings (Fig. 9: 19). There are parallels to these artefacts in the Crimea and also in a much wider area.

There are thin plain gold leaves with three dentals (Fig. 9: 11), rectangular or irregularly-shaped, and also in the form of a wild boar's figurine enlarged by engraving (Fig. 9: 24), most of which occurred in the assemblages of the early zone. In grave 313 (the early zone of period 1) there were thin gold leap-plate and eye-plate (Fig. 9: 13, 14), crumpled and placed on the top chest of the deceased; they are called so from the parallels, mostly occurring in the Bosporos. In grave 76 (the south zone of period 1), there were three almond-shaped petals possibly used as a leap-plate and an eye-plate broken into two parts (Fig. 9: 15), which also resided on the chest of the dead person, amidst the beads and other goods.

Pincers and metal beads did not concentrate in some of the cemetery zones. Metal globular bottles with a cylindrical neck (Fig. 6: 11) appeared in the early zone of period 2 (graves 6 and 106). Ceramic spindlewhorls (no less than 180 specimens; one to five pieces in 105 graves) appeared in every cemetery zone. In most cases, they were placed near femurs. Biconical spindle-whorls predominated; there also were trapezoid and truncated-cone pieces. These categories of finds are hardly relatable to some cultural context.

Assemblages from period 2 contained at least six three-layer bone/horn combs of bad preservation. The fragments of better preservation belonged to single-sided combs typical of the East Germanic tradition and those under its influence. Among them, there were attributable combs (according to: Nikitina 1969) of variant 2a of type I; variant 2 of type II or variant 3 of type I; variant 2a of type III (Fig. 6: 10).

Vault 136 in the medium zone of period 2 contained a bronze arrow-head typical of the Scythian period. By all appearance, this artefact was secondary used, possibly as an amulet.

12 There are similar pieces excavated from grave 149 in the cemetery of Belbek IV; they have been interpreted as cheek-pieces used as amulets (Gushchina/Zhuravlev 2016/1, 109, 150; 2016/2, pl. 92: 1). 
A glass inset (?) featuring a scene (Fig. 9: 22) should be mentioned specifically. It certainly deserves a particular research. This artefact was discovered on the bottom of grave 141, which had been disturbed in antiquity (medium zone of period 2), among the accumulation of fine beads.

\section{CONCLUSION}

According to the continuity in the spatial structure, predominant funeral rites, and some of the categories of finds, the cemetery of Frontovoe 3 belonged to a single population (commune), which buried there uninterruptedly, for longer than 300 years. Obviously, these persons established a wide range of connections and were open to outside influences; it was also possible that this commune incorporated the bearers of other traditions.

According to the funeral rites and grave goods, period 1 of the cemetery of Frontovoe 3 started about the late $1^{\text {st }} \mathrm{c}$. and belonged to the circle of sites of the culture tentatively called the Late Scythian. The cemetery of Frontovoe 3 was located in the south-western periphery of this culture area, near the Roman occupation zone with its centre in Chersonese, which determined many of the features of the cemetery under study. In 2018, the works in immediate vicinity from Frontovoe 3 discovered and excavated large areas of the sites partially synchronous or preceding it (for a brief account see: Rukavishnikova/Voloshinov/ Beilin 2019; Sharov 2019). The discussion on some aspects of the early history of the population which created the cemetery of Frontovoe 3 will be possible when the materials in question are published.

There are many researchers who related the final of the Late Scythian culture with the end of several settlements and sites, and the inflow of a new population, to the age of the Scythian (or "Gothic") Wars in 232-275/276 (for current reviews of the question, see Aibabin/Khairedinova 2017,33 ff.). There also are interpretations suggesting an earlier chronology of at least a part of the said turbulences in the Crimea (e. g. the fall of Scythian Neapolis in the sub-mountainous Crimea) and their connection to the Bosporans' raid of ca. 218 and/ or the Alans' expansion in the second quarter of the $3^{\text {rd }} \mathrm{c}$. (Doroshko/Ushakov 2012, with bibliography; Zaitsev $2003,45)$. However, there is not enough argument to suppose population changes in Frontovoe 3 and a group of other Crimean sites excavated by large areas, such as Neizats in the sub-mountainous area or Sovkhoz 10 near modern Sevastopol. At the moment, we are starting a new stage in the discussion of the interconnections and nature of the events and migrations in the south of Eastern Europe in the $3^{\text {rd }} \mathrm{c}$., particularly reflected by a series of innovations documented at Frontovoe 3 and other sites in the Crimea.

About the 270s, the period of stabilization started in the northern Black Sea area. It was broken by the invasion of the Huns and related peoples who appeared in the country to the west of the Don a few years earlier than $376 \mathrm{AD}$. Some researches have related this expansion to the end of the cemeteries of the type of Neizats in the sub-mountainous Crimea and Sovkhoz 10 and Frontovoe 3 in the south-western Crimea. However, the materials of Frontovoe 3 and other sites inform that these changes happened later, about the early $5^{\text {th }}$ c. or, possibly in a few cases, in the late $4^{\text {th }}$ c. (Gavritukhin et al. 2020, with the review and bibliography of this discussion).

According to the area covered by burial vault 86, one of the latest in Frontovoe 3, the number of persons buried there was smaller than supposed. There is a parallel case documented in Neizats (Khrapunov $2005,178)$. Obviously, it means that the local residents did not plan to leaver the place where they used to live. Probably, they had to leave after an invasion from the outside, most likely related with the Huns. However, they were not the Huns who moved to the Danube area from the late 370 s on, but rather another, most likely also Hunnic horde (Kazanski 2019b, 259).

All the researchers agree that the end of the cemeteries located in the sub-mountainous Crimea and partly in the south-western Crimea, the regions mostly open to the steppe, was related to their populations' migration to the southern coast (the cemeteries of the type Luchistoe) and other less approachable regions in the south-western Crimea (cemeteries of the type Skalistoe). Perhaps a more detailed analysis of the latest materials from Frontovoe 3 and other sites of similar chronology will allow the ones to answer the question of the specific direction of migration of the persons who stopped burying at Frontovoe 3 cemetery.

The unique preservation of the completely excavated cemetery of Frontovoe 3 and the rich collection of finds excavated there have placed this site into the group of reference monuments allowing the solution of a number of questions of the history of the Crimea in the Roman and Great Migration periods. The site under study possesses a great potential value for the investigations of antiquities in other countries. The in-depth research of the materials in question just started. 


\section{LITERATURE}

Aibabin 1990

Aibabin 1994

Aibabin 1999

Aibabin/Khairedinova 2008

Aibabin/Khairedinova 2014

Aibabin/Khairedinova 2017

Alekseeva 1997

Alekseeva/Sorokina 2007

Ambroz 1966

Arseneva/Domzalski 2002

Arseneva/Naumenko 1992

Arseneva/Naumenko 1994

Babenchikov 1963

Barkóczi 1988

Belov 1965

Belov 1969

Bezuglov/Iliashenko 2000

Bisembaev et al. 2018

\section{Bobrinskii 1978}

Chrzanovski/Zhuravlev 1998

Dashevskaia 1991

Diaconu 1971

Doroshko/Ushakov 2012

Feugère 1985

Gavritukhin 2010

Gavritukhin 2017

Gavritukhin 2018

Gavritukhin/Astafev/Bogdanov 2019
A. I. Aibabin: Khronologiia mogilnikov Kryma pozdnerimskogo i rannesrednevekovogo vremeni. Materialy po arkheologii, istorii i etnografii Tavrii 1, 1990, 3-86, $175-241$.

A. I. Aibabin: Raskopki mogilnika bliz sela Druzhnoe v 1984 g. Materialy po arkheologii, istorii i etnografii Tavrii 4, 1994, 89-131.

A. I. Aibabin: Etnicheskaia istoriia rannevizantiiskogo Kryma. Simferopol 1999.

A. I. Aibabin/E. A. Khairedinova: Mogilnik u sela Luchistoe 2. Raskopki 1977, 1982-1984 godov. Simferopol - Kerch 2008.

A. I. Aibabin/E. A. Khairedinova: Mogilnik u sela Luchistoe 1. Raskopki 1984 1986, 1991, 1993-1995 godov. Simferopol - Kerch 2014.

A. I. Aibabin/E. A. Khairedinova: Krymskie goty strany Dori (seredina III-VII v.). Simferopol 2017.

E. M. Alekseeva: Antichnyi gorod Gorgippiia. Moskva 1997.

E. M. Alekseeva/N. P. Sorokina: Kollektsiia stekla antichnoi Gorgippii. Moskva 2007.

A. K. Ambroz: Fibuly Iuga Evropeiskoi chasti SSSR. II v. do n. e. - IV v. n. e. Svod arkheologicheskikh istochnikov D1-30. Moskva 1966.

T. M. Arseneva/K. Domzalski: Late Roman Red Slip Pottery from Tanais. Eurasia Antiqua 8, 2002, 415-485.

T. M. Arseneva/S. A. Naumenko: Usadby Tanaisa. Moskva 1992.

T. M. Arseneva/S. A. Naumenko: Kompleks nakhodok iz podvala MB II-III vv. n. e. Vestnik Tanaisa 1, 1994, 61-113.

V. P. Babenchikov: Chornorichenskyi mohylnyk. Arkheolohychni pamiatky URSR 13 (Starodavni pamiatky Inkermanskoi dolyny), 1963, 90-123.

L. Barkóczi: Pannonische Glasfunde in Ungarn. Budapest 1988.

G. D. Belov: Steklodelie v Khersonese. Sovetskaia arkheologiia 3, 1965, 237-239.

G. D. Belov: Steklodelatelnaia masterskaia v Khersonese. Kratkie soobshcheniia Instituta arkheologii 116, 1969, 80-84.

S. I. Bezuglov/S. M. Iliashenko: Bogatoe pogrebenie gunnskoi epokhi bliz Tanaisa. Donskaia arkheologiia 1, 2000, 91-100.

A. A. Bisembaev/A. I. Khavanskii/M. N. Duisengali/A. M. Mamedov/N. M. Bairov/ V. A. Amelin: Issledovanie pamiatnikov gunnskogo vremeni $\mathrm{v}$ Aktiubinskoi oblasti v 2018 g. (predvaritelnoe soobshchenie). Kazakstan arheologijasy 1-2, 2018, 235-244.

A. B. Bobrinskii: Goncharstvo Vostochnoi Evropy. Istochniki i metody izucheniia. Moskva 1978.

L. Chrzanovski/D. Zhuravlev: Lamps from Chersonesos in the State Historical Museum Moscow. Roma 1998.

O. D. Dashevskaia: Pozdnie skify v Krymu. Svod arkheologicheskikh istochnikov D1-7. Moskva 1991.

Gh. Diaconu: Über die Fibel mit umgeschlagenem Fuß in Dazien. Dacia 15, 1971, 239-267.

V. V. Doroshko/S. V. Ushakov: O vremeni i obstoiatelstvakh gibeli Krymskoi Skifii: Alany, 224 g. Materialy po arkheologii $i$ istorii antichnogo i srednevekovogo Kryma 4, 2012, 9-12.

M. Feugère: Les fibules en Gaule Méridionale de la conquête à la fin du Ve s. ap. J.-C. Paris 1985.

I. O. Gavritukhin: Nakhodka iz Suprut v kontekste vostochnoevropeiskikh silno profilirovannykh fibul. In: A. M. Vorontsov/I. O. Gavrituhin (eds.): Lesnaia i lesostepnaia zony Vostochnoi Evropy v epokhi rimskikh vliianii i Velikogo pereseleniia narodov. Konferentsiia 2. Chast 1. Tula 2010, 49-68.

I. Gavritukhin: Glass Vessels of the Final of the Chernyakhov Culture. In: $\mathrm{Na}$ hranicích impéria. Extra fines Imperii. Jaroslavu Tejralovi k 80. narozeninám. Brno 2017, 83-109.

I. Gavritukhin: Belt sets from Alanic graves: chronology and cultural links. In: A. B. Belinskii/H. Härke (ed.): Ritual, Society and Population at Klin-Yar (North Caucasus). Excavations 1994-1996 in the Iron Age to Early Medieval cemetery. Archäologie in Eurasien 36. Bonn 2018, 49-96, 217-236, 241-244, 246-247, 255, 258-259, 262, 272, 278-279, 281-283, 289, 292-294, 297-299, 301, 308, 310-314, 316-317, $321-324,334,340,357-359,371,376$, 378, 382, 387, 392, 394, 399, 401, 403, 407, 409, 412 , pl. 5 .

I. O. Gavrituhin/A. E. Astafev/E. S. Bogdanov: Fibuly s poseleniia Karakabak. Povolzhskaia arkheologiia 3, 2019, 170-189. 
Gavritukhin/Sviridov/Yazikov 2020

Gavritukhin et al. 2020

Golofast 2006

Gushchina/Zhuravlev 2016/1

Gushchina/Zhuravlev 2016/2

Hattatt 1989

Hayes 1975

Hayes 1985

Hellström 2018

Isings 1957

Iurochkin/Trufanov 2007

Kazanski 2019a

Kazanski 2019b

Keller 1971

Khairedinova 1995

Khazanov 1963

Khrapunov 2002

Khrapunov 2004

Khrapunov 2005

Khrapunov 2008a

Khrapunov 2008 b

Khrapunov 2011

Khrapunov 2018

Khrapunov/Stoianova 2018

Kostromichev 2015

Kostsiushko-Valiuzhinich 1901

Kunina 1997a

Kunina 1997b

Kunina/Sorokina 1972

Madyda-Legutko 1986
I. O. Gavritukhin/A. N. Sviridov/S. V. Yazikov: Mogilnik rimskogo vremeni Frontovoe 3 v Iugo-Zapadnom Krymu (predvaritelnoe soobshchenie). Rossiiskaia arkheologiia 2, 2020, 91-110.

I. O. Gavritukhin/A. V. Mastykova/A. N. Sviridov/E. V. Sukhanov/S. V. Yazikov: Final mogilnika Frontovoe 3 (k izucheniiu migratsii v Iugo-Zapadnom Krymu na zakate antichnosti). Stratum plus 4, 2020, 235-247.

L. A. Golofast: Steklo iz raskopok zolnika rimskogo vremeni u podnozhiia gory Mitridat v Kerchi. Bosporskie issledovaniia 11, 2006, 309-330.

I. I. Gushchina/D. V. Zhuravlev: Nekropol rimskogo vremeni Belbek IV v Iugo-Zapadnom Krymu. 1 chast'. Moskva 2016/1.

I. I. Gushchina/D. V. Zhuravlev: Nekropol rimskogo vremeni Belbek IV v Iugo-Zapadnom Krymu. 2 chast'. Moskva 2016/2.

R. Hattatt: Ancient Brooches and Other Artefacts. A fourth selection of brooches together with some other antiquities from the author's collection. Barnsley 1989.

J. W. Hayes: Roman and Pre-Roman Glass in the Royal Ontario Museum. Toronto 1975. J. W. Hayes: Sigillate Orientali. Ceramica Romana nel Baciono Mediterraneo. Enciclopedia dell arte antica, classica e orientale. Atlante delle forme ceramiche. Roma 1985.

K. Hellström: Fibeln und Fibeltracht der Sarmatischen Zeit im Nordschwarzmeergebiet (2. Jh. v. Chr.-3. Jh. n. Chr.). Archäologie in Eurasien 39. Bonn 2018.

C. Isings: Roman Glass from Dated Finds. Groningen - Djakarta 1957.

V. Iu. Iurochkin/A. A. Trufanov: Khronologiia mogilnikov Tsentralnogo i IugoZapadnogo Kryma 3-4 v. n. e. In: Iu. P. Zaitsev/V. I. Mordvintseva (eds.): Drevniaia Tavrika. Simferopol 2007, 359-397.

M. M. Kazanski: O poiasakh s nakladnymi uzkimi plastinami iz mogilnika Luchistoe. In: E. A. Khairedinova (ed.): Problemy istorii i arkheologii srednevekovogo Kryma. Simferopol 2019, 60-64.

M. M. Kazanski: Nachalo epokhi Velikogo pereseleniia narodov na Bospore Kimmeriiskom: itogi i perspektivy. In: V. N. Zinko/E. N. Zinko (eds.): XX Bosporskie chteniia. Bospor Kimmeriiskii i varvarskii mir v period antichnosti i srednevekovia. Osnovnye itogi i perspektivy issledovanii. Simferopol - Kerch 2019, 256-265.

E. Keller: Die spätrömischen Grabfunde in Südbayern. München 1971.

E. A. Khairedinova: Busy iz mogilnika Druzhnoe. In: Iu. M. Mogarichev/I. N. Khrapunov (eds.): Problemy arkheologii drevnego i srednevekovogo Kryma. Simferopol 1995, 59-87.

A. M. Khazanov: Genezis sarmatskikh bronzovykh zerkal. Sovetskaia arkheologiia 4, 1963, 58-72.

I. N. Khrapunov: Mogilnik Druzhnoe (III-IV vv. n. e.). Lublin 2002.

I. N. Khrapunov: Etnicheskaia istoriia Kryma v rannem zheleznom veke. Bosporskie issledovaniia 6. Simferopol - Kerch 2004.

I. N. Khrapunov: Poslednie pogrebeniia v mogilnike Neizats. Materialy po arkheologii, istorii i etnografii Tavrii 11, 2005, 169-191.

I. N. Khrapunov: Sklep IV v. n. e. iz mogilnika Neizats. Problemy istorii, filologii, kultury 21, 2008, 356-392.

I. N. Khrapunov: Nakonechniki remnei iz mogilnika Neizats. Materialy po arkheologii, istorii i etnografii Tavrii 14, 2008, 61-79.

I. N. Khrapunov: Nekotorye itogi issledovaniia mogilnika Neizats. In: I. N. Khrapunov (ed.): Issledovaniia mogilnika Neizats. Simferopol 2011, 60-113.

I. N. Khrapunov: Sklep s veshchami v dogunnskom polikhromnom stile iz mogilnika Opushki. Krym v sarmatskuiu epokhu 3, 2018, 137-169.

I. N. Khrapunov/A. A. Stoianova: Ukrasheniia v pozdnerimskom polikhromnom stile iz mogilnika Opushki v Krymu. Stratum plus 4, 2018, 255-262.

D. A. Kostromichev: Azhurnye priazhki s peltovidnoi ramkoi: voprosy tipologii, khronologii i proiskhozhdeniia. Stratum plus 4, 2015, 299-356.

K. K. Kostsiushko-Valiuzhinich: Izvlechenie iz otcheta o raskopkakh, proizvedennykh v Khersonese v 1898. In: Otchet Imperatorskoi arkheologicheskoi komissii za 1898 god. St. Petersburg 1901, 99-123.

N. Z. Kunina: O bosporskom steklodelii v I-III vv. n. e. In: S. K. Sizov (ed.): Bospor i antichnyi mir. Nizhny Novgorod 1997, 39-82.

N. Z. Kunina: Antichnoe steklo v sobranii Ermitazha. St. Petersburg 1997.

N. Z. Kunina/N. P. Sorokina: Stekliannye balzamarii Bospora. Trudy Gosudarstvennogo Ermitazha 13, 1972, 146-177.

R. Madyda-Legutko: Die Gürtelschnallen der Römischen Kaiserzeit und der frühen Völkerwanderungszeit im mitteleuropaschen Barbaricum. BAR International Series 360. Oxford 1986. 
Malashev 2000

Malashev/Gadzhiev/Iliukov 2015

Mastykova 2009

Mastykova 2016

Nessel 2003

Nikitina 1969

Oldenstein 1977

Orlov 1987

Radiush 2014

Rukavishnikova/Voloshinov/Beilin 2019

Ryzhova 2003

Shabanov 2011

Shabanov 2015

Sharov 2019

Skripkin 1989

Sorokina 1962

Sorokina 1965

Sorokina 1973

Sorokina 1982

Sorokina 1987

Sorokina/Gushchina 1980

Stoianova 2004

Strzheletskii et al. 2003-2004

Sukhanov, in press

Sukhanov/Sviridov/Yazikov, in press

Sviridov/Yazikov 2019

Tejral 2011
V. Iu. Malashev: Periodizatsiia remennykh garnitur pozdnesarmatskogo vremeni. In: Iu. K. Guguev (ed.): Sarmaty i ikh sosedi na Donu. Rostov on Don 2000, 194-232. V. Iu. Malashev/M. S. Gadzhiev/L. S. Iliukov: Strana maskutov v Zapadnom Prikaspii. Kurgannye mogilniki Prikaspiiskogo Dagestana III-V vv. n. e. Makhachkala 2015.

A. Mastykova: Zhenskij kostium Centralnogo i Zapadnogo Predkavkazia v konce IV seredine VI v. n. e. Moskva 2009.

A. V. Mastykova: O proiskhozhdenii iantarnykh gribovidnykh bus-podvesok rimskogo vremeni v Ponto-Kavkazskom regione. Stratum plus 4, 2016, 173-189.

V. A. Nessel: Krasnolakovaia keramika iz mogilnika Kilen-Balka. Khersonesskii sbornik 12, 2003, 107-123.

G. F. Nikitina: Grebni cherniakhovskoi kultury. Sovetskaia arkheologiia 1, 1969, 147-159.

J. Oldenstein: Zur Ausrüstung römischer Auxiliareinheiten: Studien zu Beschlägen und Zierat an der Ausrüstung der Römischen Auxiliareiheiten des obergermanisch-raetischen Limesgebietes aus dem zweiten und dritten Jahrhundertn $\mathrm{n}$. Chr. Bericht der Römisch-germanischen Komission 57, 1977, 49-284.

K. K. Orlov: Ai-Todorskii nekropol. In: T. N. Vysotskaia (ed.): Materialy k etnicheskoi istorii Kryma VII v. do n. e.-VII v. n. e. Kiev 1987, 106-133.

O. A. Radiush: O severnoi granitse rasprostraneniia tak nazyvaemykh "kinzhalov s vyrezami". Stratum plus 4, 2014, 231-245.

I. V. Rukavishnikova/A. A. Voloshinov/D. V. Beilin: Issledovaniia pozdneskifskogo poseleniia Kermen-Burun (U steny 2) v Sevastopole. In: S. Iu. Vnukov/ O. V. Sharov (eds.): Krym - Tavrida, chast 2. Moskva 2019, 342-361.

L. A. Ryzhova: Stekliannye kanfary iz sobraniia Khersonesskogo zapovednika. Khersonesskii sbornik 12, 2003, 151-164.

S. B. Shabanov: Stekliannye sosudy iz mogilnika Neizats (po materialam raskopok 1996-2011). Materialy po arkheologii, istorii i etnografii Tavrii 17, 2011, 141-191.

S. B. Shabanov: Rimskoe steklo. Stekliannye sosudy iz sobraniia Tsentralnogo muzeia Tavridy. Simferopol 2015.

O. V. Sharov: Arkheologicheskie issledovaniia pozdneskifskogo poseleniia Frontovoe 2. In: S. Iu. Vnukov/O. V. Sharov (eds.): Krym - Tavrida 2. Moskva 2019, 239-275. A. S. Skripkin: Pogrebalnyi kompleks s uzdechnym naborom iz Kotlubani i nekotorye voprosy etnicheskoi istorii sarmatov. Sovetskaia arkheologiia 4, 1989, 172-181. N. P. Sorokina: Steklo iz raskopok Pantikapeia 1945-1959. In: I. B. Zeest/I. D. Marchenko (eds.): Pantikapei. Materialy i issledovaniia po arkheologii SSSR 103. Moskva 1962, 210-236.

N. P. Sorokina: Stekliannye sosudy iz Tanaisa. In: D. B. Shelov (ed.): Drevnosti Nizhnego Dona. Materialy i issledovaniia po arkheologii SSSR 127. Moskva 1965, 202-248. N. P. Sorokina: Stekliannye sosudy iz mogilnika Kharaks. In: R. M. Munchaev/ V. I. Markovin (eds.): Kavkaz i Vostochnaya Evropa v drevnosti. Moskva 1973, 183-189. N. P. Sorokina: Stekliannaia posuda kak istochnik po istorii ekonomicheskikh sviazei Prichernomoria i lokalnogo steklodeliia pervykh vv. n. e. In: D. L. Talis (ed.): Arkheologicheskie issledovaniia na iuge Vostochnoi Evropy 2. Trudy Gosudarstvennogo istoricheskogo muzeia 54. Moskva 1982, 40-42.

N. P. Sorokina: Glass Aryballoi $\left(1^{\text {st }}-3^{\text {rd }}\right.$ cc.) from the Northern Black Sea Region. Journal of Glass Studies 29, 1987, 40-46.

N. P. Sorokina/I. I. Gushchina: Stekliannye izdeliia iz mogilnikov pervykh vekov n. e. Iugo-Zapadnogo Kryma. In: T. B. Popova (ed.): Istoriia i kultura Evrazii po arkheologicheskim dannym. Trudy Gosudarstvennogo istoricheskogo muzeia 51. Moskva 1980, 89-100.

A. A. Stoianova: Busy i podveski iz mogilnika Neizats (po materialam raskopok 1996-2001). Bosporskie issledovaniia 5, 2004, 263-319.

S. F. Strzheletskii/T. N.Vysotskaia/L. A. Ryzhova/G. I. Zhestkova: Naselenie okrugi Khersonesa v pervoi polovine I tysiacheletiia novoi ery (po materialam nekropolia Sovkhoz-10). Stratum plus 4, 2003-2004, 27-277.

E. V. Sukhanov: Lepnaia keramika mogilnika rimskogo vremeni Frontovoe 3 (predvaritelnaia publikatsiia). Materialy po arkheologii, istorii i etnografii Tavrii, in press. E. V. Sukhanov/A. N. Sviridov/S. V. Yazikov: Lepnaia keramika mogilnika rimskogo vremeni Frontovoe 3 (o tekhnologii izgotovleniia). Kratkie soobshcheniia Instituta arkheologii, in press.

A. N. Sviridov/S. V. Yazikov: Pogrebalnye obriady mogilnika rimskogo vremeni Frontovoe 3 v Iugo-Zapadnom Krymu. Kratkie soobshcheniia Instituta arkheologii 255, 2019, 185-201.

J. Tejral: Einheimische und Fremde. Das norddanubisce Gebiet zur Zeit der Völkerwanderung. Brno 2011. 
Tsetlin 2005

Tsetlin 2010

Tsetlin 2012

Tsetlin 2013

Ushakov/Doroshko/Doroshko 2017

Veimarn/Aibabin 1993

Vnukov 2016

Whitehouse 2001

Yazikov/Sviridov/Aleinikov 2019

Zaitsev 2003

Zhuravlev 2010
Yu. B. Tsetlin: Ceramics culture: a real system and a source of historical information. In: M. I. Prudêncio/M. I. Dias/J. C. Waerenborgh (eds.): Understanding people through their pottery. Proceedings of the $7^{\text {th }}$ European Meeting on Ancient Ceramics (EMACo3) October 27-31, 2003, Instituto Tecnologico e Nuclear, Lisbon, Portugal. Lisbon 2005, 289-293.

Yu. B. Tsetlin: Experimental Research into Pottery Making. The Old Potter's Almanach 15, 2010, 6-9.

Yu. B. Tsetlin: Dreoniaia keramika. Teorija i metody istoriko-kulturnogo podkhoda. Moskva 2012.

Yu. B. Tsetlin: $50^{\text {th }}$ Anniversary of the History of Ceramics Laboratory (Institute of Archaeology, Russian Academy of Sciences). The Old Potter's Almanach 18, 2013, $16-19$.

S. V. Ushakov/V. V. Doroshko/O. P. Doroshko: Khersonesskaia sigilliata: osnovnye tipy i khronologiia (po materialam raskopok gorodishcha i mogilnika Sovkhoz-10). Istoriia i arkheologiia Kryma 6, 2017, 54-93.

E. V. Veimarn/A. I. Aibabin: Skalistinskii mogilnik. Kiev 1993.

S. Iu. Vnukov: Eshche raz o tipologii, evoliutsii i khronologii svetloglinianykh (pozdnegerakleiskikh) uzkogorlykh amfor. Rossiiskaia arkheologiia 2, 2016, 36-47.

D. Whitehouse: Roman Glass in the Corning Museum of Glass 2. Corning - New York 2001.

S. V. Yazikov/A. N. Sviridov/S. V. Aleinikov: Mogilnik pervykh vekov novoi ery Frontovoe 3. In: S. Iu. Vnukov/O. V. Sharov (eds.): Krym - Tavrida 2. Moskva 2019, 276-313.

Iu. P. Zaitsev: Neapol Skifskii (II v. do n. e. - III v. n. e.). Simferopol 2003.

D. V. Zhuravlev: Krasnolakovaia keramika Iugo-Zapadnogo Kryma pervyh vekov n. e. (po materialam pozdneskifskikh nekropolei Belbekskoi doliny). Simferopol 2010.

\title{
Pohrebisko Frontovoje 3
}

\section{Nové poznatky o kultúre Krymu v dobe rímskej a na počiatku obdobia st̉ahovania národov}

\author{
Igor Gavritukhin - Larisa Golofast - Anna Mastykova - \\ Evgeny Sukhanov - Alexey Sviridov - Sergey Yazikov
}

\section{Súhrn}

Lokalita sa nachádza 1 km západo-juhozápadne od dnešnej obce Frontovoje blízko Sevastopola. Pohrebisko z doby rímskej (328 hrobov) bolo kompletne preskúmané. Získalo sa okolo 20000 nálezov. V počiatočnom období pochovávania patrí nekropola Frontovoje do okruhu nálezísk neskoroskýtskej kultúry. Poloha blízko zóny okupovanej Rimanmi s centrom v meste Chersonézos ovplyvnila charakter týchto hrobov. Záver neskoroskýtskej kultúry sa spája s výpravou Bosporanov okolo roku 218, expanziou Alanov v druhej štvrtine 3. storočia, skýtskymi vojnami v rokoch 232-275/276. Pohrebisko Frontovoje 3 sa prestalo používat' koncom 5. storočia. Jedinečná zachovalost' úplne preskúmaného pohrebiska Frontovoje 3 spolu s bohatou kolekciou nálezov radia túto lokalitu medzi pamiatky, ktoré sú zásadné pre riešenie mnohých tém krymskej histórie v dobe rímskej a na začiatku obdobia stahovania národov.

Obr. 1. Krym. Poloha pohrebiska Frontovoje 3 a najznámejšie lokality. 1 - Frontovoje 3; 2 - Chersonézos; 3 - Sovchoz 10; 4 - Neizats; 5 - Družnoje.

Obr. 2. Pôdorys pohrebiska Frontovoje 3. a - hranica oblasti výskumu; b-hroby z doby bronzovej; c-keramika z konca 1. a prvej polovice 2. storočia; $\mathrm{d}$ - keramika z 2. storočia; e - prekrývajúce sa hroby; f - juhovýchodný okraj oblasti výskytu spôn typu Ambroz-15-II; g - severozápadný okraj oblasti výskytu spôn typu Ambroz-15-III; h - nálezy z hunského obdobia (nie staršie než r. 370); i - pracky z 5. storočia; j-m - najmladšie mince z komplexu (j1 - 1 . pol. 1. stor.; j2 - 15-175; k - koniec 2./začiatok 3. stor.; 1 - polovica 3. stor.; $\mathrm{m}-4$. stor., vrátane $\mathrm{m} 1$ - 306-337, $\mathrm{m} 2$-351-355); $\mathrm{n}$ - hrobky; o - jednoduché a dvojité hroby s výklenkami; $\mathrm{p}$ - jednoduché jamové hroby.

Obr. 3. Pohrebisko Frontovoje 3. Pohrebné zvyky. 1 - hrob 52; 2 - hrob 171; 3 - hrob 319; 4 - hrob 44; 5 - hrob 222; 6 hrob 18; 7 - hrob 154. Legenda: a - kamene; b - popol z dreva; c - zvieracia kost;' d - popol z kostí. 
Obr. 4. Pohrebisko Frontovoje 3. Keramika s červeným połahom (džbány, šálky, stolové amfory, oinochoé). 1 - hrob 183; 2 - hrob 287; 3 - hrob 5; 4 - hrob 329; 5 - hrob 201; 6 - hrob 329; 7 - hrob 79; 8 - hrob 205; 9 - hrob 313; 10 - hrob 243; 11 - hrob 293; 12 - hrob 328; 13 - hrob 162; 14 - hrob 192; 15 - hrob 292; 16 - hrob 318; 17 - hrob 300; 18 - hrob 158; 19 hrob 96; 20 - hrob 280; 21 - hrob 108; 22 - hrob 322.

Obr. 5. Pohrebisko Frontovoje 3. Keramika s červeným potahom (iné tvary) a nádoby vytočené na kruhu (20). $1-$ hrob 317; 2 - hrob 320; 3 - hrob 260; 4 - hrob 227; 5 - hrob 316; 6-hrob 304; 7 - hrob 292; 8 - hrob 304; 9 - hrob 278; 10 - hrob 52; 11 - hrob 104; 12 - hrob 104; 13 - hrob 323; 14 - hrob 136; 15 - hrob 297; 16 - hrob 276; 17 - hrob 111; 18 hrob 125; 19 - hrob 137; 20 - hrob 41; 21 - hrob 314.

Obr. 6. Pohrebisko Frontovoje 3. Ručne formované nádoby (1-7), amfory (8,9), hrebeň (10), fragmenty flaše (11), korálik (13), súčasti konských postrojov $(12,14,15)$, fragmenty skriniek a klúče (16-20), pyxis (21). 1 - hrob 52; 2 - hrob 205; 3 - hrob 137; 4 - hrob 154; 5 - hrob 52; 6 - hrob 178; 7 - hrob 96; 8 - hrob 170; 9 - hrob 136; 10 - hrob 6; 11 - hrob 106 ; 12, 14, 15 - hrob 319; 13 - hrob 41; 16 - 19 - hrob 151; 20 - hrob 232; 21 - hrob 322. Mierka: a - 1-9; b - 10-21.

Obr. 7. Pohrebisko Frontovoje 3. Sklenené nádoby. 1, 2 - hrob 51; 3 - hrob 105; 4 - hrob 89; 5 - hrob 65; 6 - hrob 266; 7 hrob 46; 8, 9 - hrob 85; 10 - hrob 202; 11 - hrob 83; 12 - hrob 3; 13 - hrob 94; 14 - hrob 3; 15 - hrob 62; 16 - hrob 298; 17 - hrob 202; 18 - hrob 286; 19 - hrob 61; 20 - hrob 5; 21 - hrob 70; 22 - hrob 166; 23 - hrob 244; 24 - hrob $304 ; 25$ hrob 263; 26 - hrob 304; 27 - hrob 319.

Obr. 8. Pohrebisko Frontovoje 3. Koráliky a náhrdelníky. 1-4 - hrob 33; 5 - hrob 89; 6, 7 - hrob 327; 8 - hrob 31; 9 , 10 hrob 13; 11-13 - hrob 174; 14, 15 - hrob 63; 17-20, 23-27, 34-43, 78 - hrob 300; 21 - hrob 287; 22 - hrob 236; 28-31 hrob 95; 32, 33 - hrob 236; 44 - hrob 22; 45 - hrob 327; 46 - hrob 19; 47 - hrob 123; 48-50 - hrob 128; 51, 55, 56 - hrob 8; 52 - hrob 59; 53 - hrob 96; 54 - hrob 236; 57-60, 67-71, 76 - hrob 205; 61, 62 - hrob 318; 63 - hrob 238; 64 - hrob 123; 65, 66 - hrob 202; 72-74 - hrob 327; 75 - hrob 325; 77 - hrob 236; 79 - hrob 75. Mierka: a - 1-75; b - 76-78; c - 79.

Obr. 9. Pohrebisko Frontovoje 3. Prívesky, kovania, sklenená vložka a jej sadrový odliatok (22, 22a). 1, 2 - hrob 287; 3 - hrob 205; 4, 8 - hrob 33; 5, 16 - hrob 312; 6-hrob 300; 7 - hrob 273; 9 - hrob 240; 10 - hrob 8; 11, 24 - hrob 317; 12 , 17 - hrob 257; 13, 14 - hrob 313; 15 - hrob 36; 18 - hrob 112; 19 - hrob 6; 20 - hrob 21; 21 - hrob 319; 22 - hrob 141; 23 hrob 208. Mierka: a - 1-21, 23; b-22, 24.

Obr. 10. Pohrebisko Frontovoje 3. Náušnice, prstene, náramky. 1 - hrob 136; 2 - hrob 16; 3 - hrob 13; 4 - hrob 27; 5, 6-hrob 312; 7 - hrob 3; 8, 9 - hrob 232; 10 - hrob 60; 11 - hrob 300; 12 - hrob 184; 13 - hrob 234; 14 - hrob 320; 15 - hrob 154; 16 - hrob 33; 17 - hrob 158; 18, 21 - hrob 21; 19 - hrob 230; 20 - hrob 145; 22 - hrob 85; 23 - hrob 78; 24 - hrob 17; 25 hrob 234;26 - hrob 75. Mierka: a - 1-7, 11-26; b-8-10.

Obr. 11. Pohrebisko Frontovoje 3. Spony, pracky, kovania opaskov a nákončia. 1,2 - hrob 178; 3, 4, 9 - hrob 172; 5 hrob 136; 6 - hrob 52; 7 - hrob 16; 8 - hrob 20; 10 - hrob 94; 11 - hrob 175; 12 , 14 - hrob 94; 13 - hrob 45; 15 - hrob 9; 16 - hrob 106; 17 - hrob 9; 18 - hrob 13; 19 - hrob 62; 20 - hrob 3; 21 - hrob 69; 22 - hrob 3; 23 - hrob 112; 24 - hrob 199; 25 - hrob 170; 26 - hrob 233; 27 - hrob 326; 28 - hrob 287; 29 - hrob 234; 30 - hrob 200; 31 - hrob 170.

Preklad Mgr. Viera Tejbusová

Igor Gavritukhin

Institute of Archaeology

of the Russian Academy of Sciences

19 Dmitriia Ulianova Str.

RU - 117292 Moscow

igavritukhin@gmail.com

Dr. hab. Anna Mastykova

Institute of Archaeology

of the Russian Academy of Sciences

19 Dmitriia Ulianova Str.

RU - 117292 Moscow

amastykova@mail.ru
Dr. Larisa Golofast

Institute of Archaeology

of the Russian Academy of Sciences

19 Dmitriia Ulianova Str.

RU - 117292 Moscow

larisa_golofast@mail.ru

Dr. Evgeny Sukhanov

Institute of Archaeology

of the Russian Academy of Sciences

19 Dmitriia Ulianova Str.

RU - 117292 Moscow

sukhanov_ev@mail.ru
Alexey Sviridov

Institute of Archaeology

of the Russian Academy of Sciences

19 Dmitriia Ulianova Str.

RU - 117292 Moscow

a_sviridov@mail.ru
Serge Yazikov

Institute of Archaeology

of the Russian Academy of Sciences

19 Dmitriia Ulianova Str.

RU - 117292 Moscow

sergei.yazikov2012@yandex.ru 